Baltac1, A. (2019). Praetorianistic Behavior Forms: An Investigation of School Principals. Bartın University Journal of Faculty of Education, $8(1), 103-137$.

Bartın University Journal of Faculty of Education, 8(1), 103-137

Bartın Üniversitesi Eğitim Fakültesi Dergisi, 8(1), 103-137

buefad.bartin.edu.tr

\title{
Praetorianistic Behavior Forms: An Investigation of School Principals
}

\author{
Ali Baltaci*a
}

\begin{tabular}{l} 
Article Info \\
\hline DOI: 10.14686/buefad.422958 \\
\hline Article History: \\
Received $\quad 11.05 .2018$ \\
Accepted 10.12 .2018 \\
Published $\quad 01.02 .2018$ \\
\hline Keywords: \\
Praetorianism, \\
Praetorianistic behavior, \\
School principal. \\
\hline Article Type:Research Article
\end{tabular}

\begin{abstract}
Praetorianism is an administration system where the military takes an active role in political decisions openly or covertly. The purpose of this study is to determine the levels of school principals' praetorianistic behavior. This research was designed with a descriptive scanning model. The target universe of the research includes 370 school directors working in state and private secondary schools in 25 districts of Ankara. In the research, the entire universe was reached and a "complete counting" technique was used. Data of the study were obtained using the praetorianism scale developed by the researcher. The data were analyzed using descriptive statistical methods. According to the results of the study, the most praetorianistic behavior of the school principals' is 'helpfulness'. However, 'authoritarianism', 'sordidness', 'compelling', 'negative criticism', and 'orientation' are the praetorianistic behaviors of school principals. The praetorianistic behaviors of school principals differ significantly according to the variables of gender, educational status, school type, and sector. On the other hand, it has been determined that professional tenure does not differentiate between praetorianistic behaviors.
\end{abstract}

\section{Praetoryanist Davranış Kalıpları: Okul Müdürleri Üzerine Bir İnceleme}

\begin{tabular}{l} 
Makale Bilgisi \\
\hline DOI: $10.14686 /$ buefad.422958 \\
\hline Makale Geçmişi: \\
Geliş $\quad 11.05 .2018$ \\
Kabul $\quad 10.12 .2018$ \\
Yayın $\quad 01.02 .2018$ \\
\hline Anahtar Kelimeler: \\
Praetoryanizm, \\
Praetoryanist davranış, \\
Okul müdürü. \\
\hline Makale Türü:Araştırma \\
Makalesi \\
\end{tabular}

\section{$\ddot{O} \mathbf{z}$}

Praetoryanizm, askeri veya sivil otoritelerin siyasi ve sosyal kararlarda açık veya gizli olarak aktif bir rol aldığ 1 vesayete dayalı bir yönetim sistemidir. Bu çalışmanın amacı, okul müdürlerinin praetoryanist davranış biçimlerini gösterme düzeylerinin belirlenmesidir. $\mathrm{Bu}$ araştırma, betimsel tarama modeli ile tasarlanmıştır. Araştırmanın hedef evrenini, Ankara ilinin 25 ilçesinde resmi ve özel ortaöğretim okullarında görev yapmakta olan 370 okul müdürü oluşturmaktadır. Araştırmada evrenin tamamına ulaşılarak, "tam sayım" tekniği kullanılmıştır. Çalışmanın verileri, araştırmacı tarafından geliştirilen praetoryanizm ölçeği kullanılarak elde edilmiştir. Veriler, betimsel istatistik yöntemleri kullanılarak analiz edilmiştir. Çalışma sonuçlarına göre, okul müdürlerinin en çok sahip oldukları praetoryanist davranışın 'yardımseverlik' olduğu sonucuna ulaşılmıştır. Bununla birlikte 'otoriterlik', 'yararcılık', 'zorlayıcılık', 'olumsuz eleștiri', 'sınırlayıcılık ve 'yönlendiricilik' de okul müdürlerinin sahip olduğu praetoryanist davranışlardandır. Okul müdürlerinin praetoryanist davranışları, cinsiyet, eğitim durumu, okul türü ve eğitim kolu (sektör) değişkenlerine göre anlamlı bir şekilde farklılaşmaktadır. Buna karşın mesleki kıdemin praetoryanist davranışları farklılaştırmadığı belirlenmiştir.

\footnotetext{
*Corresponding Author: a.baltaci@alparslan.edu.tr

${ }^{a}$ Ass.Prof Dr., Muş Alparslan University, Muş/Turkey ORCID: https://orcid.org/0000-0003-2550-8698
} 


\section{Introduction}

In the literature of management sciences, the differences between eastern and western cultures have been tried to be determined for the last fifty years; despite work dynamics based on the rational reality of the West, the collectivist traditions of the East are studied. In Turkey which is situated as a bridge between the east and west world and the structural features of working life are organized in western style, the social and cultural formation exhibits the cultural characteristics of the East (Dikili, 2014). In this context, the harmony between westernoriented designs and with the social and cultural dynamics of the East brings certain difficulties. However, Western-based organizations and models of organizational behavior forms will be difficult to become operational in traditional eastern patterned societies such as Turkey (Güçlü, 2003). In the praetorian management paradigm, which is an important concept of political science and is frequently observed in our country, the manager or leader owns the employee not only in business life but also in private life issues with an unconditional protection motive (Nordlinger, 1977) and plays a dominant role in his life (Decalo, 1975). The leader seeks his / her employee to provide prosperity in the workplace and in private life and to make mutual benefit possible (Danopoulos and Zirker, 2002). In such a case, the employee often shows respect, loyalty, and obedience to his / her manager (Egretau, 2016). On the other hand, in individualist cultures dominated in the western world, it is not desirable that the manager or leader should be concerned with the issues that concern the private life of his/her employee and have a persistent protective attitude towards him/her (Jarausch, 2014). Since Turkey is also considered to have collectivist culture characteristics, praetorianism is identified as an important concept for our schools.

While praetorian school management models are identified as a repressive (Rizvi, 2015), anti-democratic (Cunliffe, 2014), and illiberal (Raviot, 2017; Hansen and King, 2000) situation in Western literature, it is seen that studies based on the East have evaluated praetorianism in the context of a positive relationship or mutual benevolence (Ma and Tsui, 2015), protectionism and enthusiasm (Ling, 2003). Praetorianism discussed as a form of anti-democratic administration in political science literature (Bowman, 2002; Decalo, 1975), appears as a new and contemporary concept in educational science literature. The main motivation of this research is that there are not any studies that examine the praetorianistic behavioral characteristics of managers or school principals in general in the literature of Turkish management and educational sciences. This study focuses on the concept of praetorianism and the extent to which school principals exhibit praetorian behavior in educational organizations.

\section{The Concept of Praetorianism}

Organization management is based on internal politics and power balances. Internal politics is the relationship of employees to each other, while power balance is the form of this relationship. The power balance in the organization has been the subject of debate in the literature. One of the important concepts of political science is 'praetorianism' which focuses on the balance of power in the organization. In general, terms of praetorianism means control of the state or organization, disregarding the freedoms of a person or group, another individual, or a group. In praetorianism, there is a force that seizes power, thinks only of the well-being of the people and acts with the motivation to protect them (Bowman, 2010). The praetorian means "guards, legionnaires, etc." in Latin is the name given to specially trained guards in charge of protecting the emperor during the Roman Empire. The guards, while guarding the emperor, also offer him unconditional support for vital issues. The concept of Praetorianism, which has been converted in time, has been used in to mean controlling the state organs of military tutelage. Praetorianism is also called an illiberal democracy device, in which a military or civil group seizes state administration in an antidemocratic manner. In addition, praetorianism emerged during the Roman Empire as a result of the idea of 'social prosperity' in which the state or a group assumed the role of protecting and helping citizens. In essence, in order to ensure social well-being the government limits its citizens by interfering with their living spaces, while enabling them to continue their lives (Ben-Eliezer, 1997). Praetorianism is a concept that considers the mere well-being of the periphery by acting as a guardian or custodian. Furthermore, praetorianism is defined philosophically as protecting someone's goodness, without his intervention, to the extent of limiting his freedom (Hen-Tov and Gonzalez, 2011). Praetorianism is the involvement of a person in their lives, focusing on the benefits or advantages of the people except him/her, protecting them at the expense of life, and going through various decisions or arrangements, ignoring people's desires and thoughts (Herspring, 1992). At this point, the belief that the decisions and regulations took and the methods of protection are the right choices for the person is examined together with the concept of praetorianism. Praetorianism also includes inadequate perceptions and criticism of persons outside him/her. Criticism in Praetorianism is often a habit of guardianship; as the level of criticism increases, the possibility of interfering with the freedoms is also increasing. In the name of others, the praetorianist (guardian) is 
the person who implements the protection action for their well-being; the person whom the praetorianistic thinks is protected is called 'praetoriad' (Peruzzotti, 2004).

In order to be able to talk about praetorianism in terms of interpersonal relations or organizational behavior, it is necessary to prevent the actions and choices with the autonomous preferences of the individual affected by praetorianistic behaviors. At this point, praetorianism is not to be willing to interfere with the choices, wants and needs of others, rather to intervene and to protect them from social life, with the desire to avoid harm and to be useful (Archer, 1990). Praetorianism is associated with various concepts in the literature such as 'protective dictatorship', 'legitimate power', 'guardian angel', 'military guardian'. Praetorianism is to approach people with warm but stealthy intentions and to make them feel that they are in their best interest. The concept, however, includes an intention to control people with a totally benevolent motive (Decalo, 1975). In this respect, praetorianism resembles a throne game, which is used to seize power. The main assumption of praetorianism constitutes that "decisions can be made to benefit individuals or groups on behalf of an individual or group with little or no harm, or rules and restrictions can be placed and the governing can be seized" (Raviot, 2017). However, the legitimacy of praetorianist practices should be discussed in situations where individuals or groups do not want to be treated as such in such a way (Nordlinger, 1977). Especially in the public sphere that started to normalize after the military coup, actions and discourses against praetorianism are frequently encountered. In everyday life, examples of praetorianist practice in the private and public sphere, and frequently in working life, are often seen. Although there is no military tutelage referred to here, every kind of guardianship is called a praetorianist behavioral pattern if it contains intense protection (McLauchlin, 2010). Another reason that praetorianism is important is that it is one of the controversial areas of political science and applied ethics. At this point, it is also significant to have tensions between individual autonomy and its boundaries, respect for the personality rights of others, benefits of others, freedom of one's own decisions, and the boundaries of freedom (Bowman, 2002).

When a military and civilian authority is considered as an attempt to seize legitimate power, the nature of praetorianism is transformed into a rather intricate and controversial concept that brings about various problems. At this point, it is difficult to understand the concept that one side is talking about 'intention to be useful' while the other side is 'pressure, compulsion or domination' (Danopoulos, 1984). The Praetorian watches the interests, health, life or safety of the person he protects, but intervenes in his freedoms and choices. Thus, restricting the individual is legitimized (Adeniran, 1985). The freedom of individuals to make their own decisions and the responsibility of protecting and preventing the interests of others is a major area of conflict for the concept of praetorianism. However, if the person is free to make a choice or to take action in contrast to his or her own benefit or interest, involvement in his decisions suggests praetorianism (Cann and Danopoulos, 1998). However, praetorianism emphasizes the intensive conservation behavior as well as the passing of one's basic rights to a guardian. In addition, many people in the social system justify praetorianism as their involvement in the freedom of physiological or psychological illnesses and disabilities, insufficiency, and the freedom of persons who are directly or indirectly limited to individual choices (detainees and convicts, drug users, etc.) (Adams and Balfour, 2014). It is not the case here that the administration of the state is seized by a military or civilian group. The person does not have the power to act with free will and to protect himself. It is also noteworthy that the views of praetorianism in the interests of the person, even if it is for the benefit of the person, cannot be justified by the obstruction or limitation of the freedom of those who have the right to choose. It can be argued that the philosophical origins of praetorianism are based on Kant, criticizing the "imperium praetoriane", which can restrict the freedom of subjects with a beneficent view (Baltac1, 2018; Danopoulos and Zirker, 2002).

In social structures that accept military tutelage more easily, praetorianism has emerged as a social tradition, but it has defeated the liberal thought that has built up in western culture. At this point, the form of praetorian relationship, which is an important part of the eastern culture, has an illiberal form due to the form of collectivist formation and the wide power distances of the social and cultural structure of the east (Ling, 2003). The form of praetorian relationship that the individualistic cultural dynamics of the west sees as negative and implies an antidemocratic device includes attitudes and behaviors such as guiding, authority obedience and loyalty, which are the main principles of Confucius teaching at the base of eastern philosophy (Kovalewski, 1991). It can be said that the Turkish culture is similar to the eastern cultures and have a collectivist structure and wide power distances like them. In this respect, it can be stated that the Turkish social and working experience adopts the praetorian relation form. In the individualistic social structure of the West, the concept of praetorianism is associated with managers who limit citizens or employees' rights and freedoms, interfere with their way of life and their private lives, and criticize them in public. The concept of praetorianism, which has a negative meaning in Western 
literature, is regarded as 'protective dictatorship' or 'a secret and insidious form of discrimination' and 'authoritarian management concept' (Bowman, 2010). Whereas, the concept of praetorianism also includes behavior that is incompatible with authoritarianism such as generosity, goodwill, protection, and care. However, advocacy of discipline and control factors in western literature is linked to cultural differences between eastern and western (Egreteau, 2016).

Praetorianism owing to military traditions, such as Turkey, the concept is quite compatible with a patterned eastern collectivist society. It is also compatible with the Turkish traditions that the manager is involved in the employees' experiences, trying to help employees, to take decisions that they think will be best for them and to keep them at all costs. However, it is stated that the content of the concept of praetorianism started to change in this context, especially in the collectivist cultures, with the recent technological developments of the people towards individual life and individualism (Raviot, 2017). In the following section, sub-dimensions of praetorian behavior are examined.

\section{Sub-Dimensions of Praetorianistic Behavior}

In order to explain the concept of Praetorianism, it is necessary to determine the basic behavioral patterns underlying this behavior. In the first period studies on praetorianism in the literature, the concept was examined in a structure without sub-dimensions. In early studies, praetorianism was seen as an authoritarian governance mentality based on military tutelage. However, as conceptual framework debates on praetorianism have developed to include eastern culture, various sub-dimensions have begun to be mentioned. Adams and Balfour (2014) studied three sub-dimensions of praetorianism: conservative, benevolent, and totalitarian. Gaub (2017) examined the concept in four sub-dimensions that he identified as helpful, compelling, utilitarian, and beneficial praetorianism. In addition, the concept of praetorianism has been further examined in three sub-dimensions conceptualized as negative criticism, guiding and limiting (Cunliffe, 2014). In this study, these dimensions will be outlined.

Negative Criticism. Criticism in the praetorianistic context, an instrument of illiberal democracy, is an array of discourses or actions that emphasize the difference between the potential and performance of employees. An organizational manager who constantly criticizes his employees thinks that this is the only way that they can achieve their goals and achieve organizational discipline. Although criticism emphasizes the nature that develops the individual, negative criticisms that emphasize the shortcomings of employees do not allow for the development of individual potential. The organizational manager thinks that he knows the job better than employees and he makes them feel it. There is a tense atmosphere in the business environment. It is an important feature of the behavior of this sub-dimension that the manager closely observes the activities of an employee or is sometimes hard and rude to employees like a guard (Baron, 1988).

Compelling. The compelling, which is expressed as a compulsion of the administrators to compete with their governments and to force the rulers to accept certain values, is the continuous supervision of the public sphere and the manipulation of the public sphere in favor of management (Egreteau, 2016). On the basis of compelling praetorianism, the mainstream view adopted by the administration is to be accepted without being changed by the rules. The managed ones are forced to do certain behaviors and for a time their behavior is manipulated in the direction they are intended; so that a change of behavior is provided in the ruled. The praetorianist administrator generally applies the "Compulsive Diplomacy Strategy". According to this strategy, within a democratic organizational system, the decision maker with managerial responsibility presents an alternative between different solution methods. A certain level of social pressure is created in order for a newly joined or incompatible employee to acquire the organizational values desired by the manager. Compelling is like directing, but it is actually a visible form of domination (Jarausch, 2014).

Restrictiveness. In the restrictive sub-dimension of praetorianistic behavior, although the manager observes the basic freedoms of the employees, it is the case of limiting these freedoms. The manager, who exhibits restrictive behaviors, tries to be fair in the distribution of duties among the employees (Alexander, 2001). The restriction includes not only the limitation of the work environment of the employee but also the restraint of the private life to a certain extent. Clothing style, break times and yearly permits in the working environment are limited by the manager. Even the manager intervenes in the communication between employees (Hansen and King, 2000).

Helpfulness, Positiveness or Good Intention. It is known that a praetorianistic relationship is usually preceded by good intentions, positive and helpful behaviors. Then the praetorianistic leader legitimizes his domination by using this positive state (Maier and Seligman, 1976). Managers help his/her employees to solve 
their problems that encounter in their work and personal lives. Managers are prone to offering their employees work environment, time, and other variables, to stretch in favor of employees and generous rewards and incentives to employees. At this point, the motivating power behind this generosity and care that is at work is a concern for employee well-being, but since praetorianism is the control of the person, there can be a constant tension between the manager and the employee. In terms of employees demonstrate commitment towards the praetorian employer, it is seen as a way of giving back to its sincere generosity and care, in most cases, the manager is implicitly obsessed with fear or frustration (Seligman, 2005).

Authoritarianism. The ruler in the authoritarian praetorianist attitude is the sovereign of absolute power in the organization. All communication and business processes within the organization are strictly monitored and constantly controlled. Restrictive applications, such as controlling work environments with visual recorders (cameras, etc.) or tracking work inputs and outputs with electronic controllers, are a result of authoritarian behavior patterns. The authoritarian ruler also thinks that he has the right to ask for an absolute commitment to himself and organization form employee. Employees who are exposed to authoritarian praetorian behavior are reluctant and non-obedient to the executives and have low job satisfaction. Authoritarian praetorianism also obliges employees to comply with strict work discipline. The reason for the establishment of a definite authority and control system for employees is the assumption that the absolute well-being of employees is considered and that they must be protected continuously. The authoritarian praetorian manager takes decisions alone; thinks that democratic processes within the organization are ineffective and that employees are in a state of incapacity that must be constantly protected (Altemeye, 1988; Giroux, 2018).

Orientation. Preatorianistic orientation is different from the basic exercises or orientation concepts commonly used in the literature. It is an orientation that is carried out with absolute will of the manager. It is the organization manager's control of the execution of all actions, which are directly involved in the work done, the decisions taken and the social processes within the organization. The manager interferes with the problems that the employees can solve between themselves and manipulates the conflicts. The manager, directing employees in the direction they want, intervenes in the career development of employees and directs them on their own initiative. The manager, demanding his employees to work according to the principles he has set, controls all the processes within the organization. The manager sees himself as the guardian of the employees and asks the employees to obey him (Gaub, 2017).

Benefaction or Sordidness. The manager treats employees well because of his concern about completing the job. The benefactor/sordidness praetorian managers desire to serve for their own purposes and show the features of Makiavelistic personality. Individuals with this feature sets a distance from other employees and act on the results of employee' work. They like to use their employees for their own purposes and act according to the conditions of their situation. In this form of relationship, although the situation is similar to the win-win strategy, in the beginning, later on it is understood by the employee that the winner is the manager (Bowman, 2010)

\section{Praetorianism in School Administration}

As a means of liberal democracy, decision-making processes and financial accountability mechanisms are gradually becoming a centralized structure, encouragement of competition between schools and intensification of discussions on school performance (Mulford, 2003), led to the emergence of praetorian managers who were student-centered and sensitive to ethical values and possessed the characteristics of a transformative leadership. The unraveling of the individual and organizational causes behind the praetorianist managerial behavior have transformed the praetorianism into an important occupation for researchers seeing them as the pioneers of change, innovation and entrepreneurial activities (Eyal and Kark, 2004). In western societies, however, antidemocratic and illiberal tendencies such as praetorianism are not welcomed.

The increasing complexity of the education system makes it difficult for employees to adapt. In such a complexity, it is imperative that employees are managed with more effective ethical values. It is possible to encounter excessive protective praetorianistic behaviors in schools. Especially early childhood schools may exhibit more complex praetorian behavior than other schools. Kindergarten and elementary schools have teachers and administrators who are dressed in praetorianistic behavior patterns. It is possible that teachers, school administrators, and other staff at the school show praetorian behaviors for the child as a very beneficent praetorianism rather than a sordidness praetorianism. In addition, the praetorianist approach of school administrators to teachers and other employees suggests a 'compulsive, authoritarian and restrictiveness' praetorianism (Beehner, 2018). 
In the literature, especially in the 20th century, it seems that the approaches towards school organization and management are more concerned with technical, economic and social problems, the orientation towards praetorianism is not over-examined or mixed with different concepts. However, praetorianism is an important concept of politics and management science, and its social influence is very apparent. However, the praetorian behavior is not new within the education system. Praetorian behavior is often seen in schools, which are an important part of social structure. It is known that both school administrators and teachers exhibit different kinds of praetorian behaviors, for different purposes. In Turkish social sciences literature, praetorianism was not studied from educational sciences perspective. Again, in the Turkish educational science literature, there was no research showing the praetorian behavior forms of school principals. It is thought that this study will be one of the leading studies in this area.

This study focuses on display of the behavior of praetorianism according to the views of school principals. The study included not only public institutions but also opinions of the administrators in private institutions. The purpose of this study is to determine the levels of school principals' attitudes toward praetorian behaviors. In addition, it is aimed to present different and original data to the literature and to open new fields of study in the management science in general and educational science literature in particular. The measurable aims of this study are shown below.

1. How do school principals exhibit the behavior of praetorianism?

2. Are the opinions of the school principals regarding the sub-dimensions of praetorianism differentiated significantly with the variables of gender, professional tenure, education status, sector, and school type?

\section{Method}

\section{Research Design}

This research was designed with a descriptive scanning model, which is included in the quantitative research paradigm. In the descriptive screening model, the research problem is trying to be determined within its own context. A descriptive screening model is a research approach that aims to describe the past or present as it exists (Vogt, 2006).

\section{Study Group}

Preliminary Application Sample. In this study, a pre-implementation group was established to determine that the praetorian behavior scale developed for this study could be used for the main application. The preliminary application of the scale was conducted on secondary school principals determined by simple random sampling method, which was not included in the research sample, and an in-service training activity organized by the General Directorate of Human Resources of the Ministry of National Education in Antalya. The school principals in the preliminary application consist of 159 school principals working in the provinces of Trabzon, Rize, Artvin, Ordu, Giresun, Bayburt, Gümüşhane and Samsun and showing similarity with the sample and not participating in the main application. Within the scope of the application, the researcher interviewed in person with school principals (participants). Participants were requested to fill in the scales and the completed scales were collected by the researcher.

Main Application Sample. The target universe of the research is composed of 370 school directors working in state and private secondary schools in 25 provinces of Ankara. In the study, the entire universe was reached and a "complete counting" technique was used. Information on participants is shown in Table 1. 
Table 1. Demographic information of school principals

\begin{tabular}{|c|c|c|c|c|}
\hline Variables & Subcategories & $\mathbf{N}$ & $\%$ & Total \\
\hline \multirow{2}{*}{ Gender } & Female & 86 & 23,24 & \multirow{2}{*}{370} \\
\hline & Male & 284 & 76,76 & \\
\hline \multirow{3}{*}{ Professional Tenure } & 15 years and less & 194 & 52,43 & \multirow{3}{*}{370} \\
\hline & $16-25$ years & 134 & 36,22 & \\
\hline & 26 years and more & 42 & 11,35 & \\
\hline \multirow{2}{*}{ Graduation level } & Undergraduate & 291 & 78,65 & \multirow{2}{*}{370} \\
\hline & Graduate & 79 & 21,35 & \\
\hline \multirow{2}{*}{ Sector } & Public & 319 & 86,22 & \multirow{2}{*}{370} \\
\hline & Private & 51 & 13,78 & \\
\hline \multirow{3}{*}{ School Type } & General Secondary Education & 173 & 46,76 & \multirow{3}{*}{370} \\
\hline & Vocational and Technical Secondary Education & 124 & 33,51 & \\
\hline & Religious Education & 73 & 19,73 & \\
\hline
\end{tabular}

According to Table $1,76.76 \%$ of participants were male and $78,65 \%$ had education at undergraduate level. It was determined that $52.43 \%$ of the participants have 15 years or less in term of professional tenure, and $86.22 \%$ were employed in state schools. It was determined that $46,76 \%$ of the participants were in general secondary schools (Anatolian High School, Science High School, Social Sciences High School), 33,51\% of the students are in vocational and technical secondary schools (Vocational high school, Anatolian vocational high school, Health vocational high school, Multi-program high school, Fine art high school, Sports high school etc.), and 19,73\% of them are working in religious schools (Imam-Hatip High School, Anatolian Imam-Hatip High School, Imam-Hatip Science and Social Sciences High School and Project Schools).

\section{Data Collection Tool}

The "Praetorianistic Behavior Scale" used in this study was developed by the researcher by using related works in the literature (Bowman, 2010; McLauchlin, 2010; Jarausch, 2014; Egreteau, 2016; Raviot, 2017; Giroux, 2018) It has already been determined in the literature that there is no scale that takes praetorian behavior characteristics. This has made it necessary to develop a new scale for use in this study. At this point, a pool of items was created by the researcher, including all sub-dimensions of praetorian behavior, and a draft scale of 81 items was prepared from the pool of items. The 81 -item draft scale that was prepared was presented to scientists in order to provide 'scope validity'. As it is known that the concept is on an interdisciplinary level, the scale has also been given a group consisting of 1 sociologist, 1 psychologist, 3 school principals and 1 Turkish linguistics specialist and according to the received feedback, it has been decided to remove 14 items from the scale. Exploratory Factor Analysis (EFA) was performed to determine to factors. At this point, Kaiser-Meyer-Olkin (KMO) value for analysis was found to be 0.968 and Barlett's test was significant ( $\mathrm{p}<0.01$ ). Preliminary data were determined to be appropriate for factor analysis. Then, exploratory factor analysis was applied to the dataset. In the factor analysis, the lowest factor value that a variable should have is suggested.30 (Sijtsma, 2009). Eleven items, which are lower than the factor value of .30 , and 4 cross loading items were removed from the scale. In the exploratory factor analysis (EFA), it is recommended that the item-total correlations of the factors constituting the factors to be at least .20. Accordingly, 3 items were omitted because the item-total correlation was smaller than .20. As a result, it was found that seven factors scattered in 49 items and these factors explained $78.37 \%$ of the total variance.

The sub-dimensions of the 'Praetorian Behavior Scale' are named in accordance with the discussions in the literature (negative criticism, compelling, restrictiveness, helpfulness, authoritarianism, orientation, and sordidness). The sample item for the negative criticism dimension is "I think that my criticism of the employees is an opportunity for them to develop themselves". Example item for the dimension of compelling: "I enforce employees to comply with the values and rules of association". Example item for the restrictiveness dimension: "I do not allow employees to work as they would in our business environment". An example of the dimension of 
helpfulness, "I support them in the material and spiritual problems of my employees, I try to help them solve the problems". An example of the authoritarian dimension: "I expect my employees to fulfill my orders unconditionally". The sample item for the dimension of sordidness: "My benefits take precedence from the benefits of my employees". The sample item for the orientation dimension is: "It is important to me that my employees work in the way I set out".

The reliability of the 'Praetorianistic Behavior Scale' was determined by Cronbach's alpha ( $\alpha$ ) and composite reliability coefficients. In Cronbach's alpha coefficient, the factor loadings and error variances of the items in the scale are equal; in the composite reliability coefficient, it is suggested to use the factor loadings and in cases where the error variances are different (Bland and Altman, 1997). For this reason, the composite reliability coefficient in the reliability tests of multidimensional scales is more stable than the Cronbach's alpha coefficient (Rodriguez, Reise, and Haviland, 2016). At this point, it has been decided to determine the composite reliability values in addition to the Cronbach's alpha values calculated for each factor. The calculated Cronbach's alpha coefficient of the Praetorianistic Behavior Scale and the validated composite reliability coefficient values are shown in Table 2.

Table 2. Reliability coefficients of the Praetorianistic Behavior Scale

\begin{tabular}{lcccc}
\hline Factors & $\begin{array}{c}\text { Total Item } \\
\text { Number }\end{array}$ & $\begin{array}{c}\text { Explained } \\
\text { Variance } \\
\text { Ratio (\%) }\end{array}$ & $\begin{array}{c}\text { Cronbach's } \\
\text { Alfa ( } \boldsymbol{\alpha}) \\
\text { Coefficient }\end{array}$ & $\begin{array}{c}\text { Composite } \\
\text { Reliability } \\
\text { Coefficient }\end{array}$ \\
\hline 1. Negative criticism & 7 & 12.26 & .83 & .86 \\
2. Compelling & 8 & 12.13 & .82 & .85 \\
3. Restrictiveness & 7 & 12.28 & .84 & .89 \\
4. Helpfulness & 6 & 10.45 & .81 & .83 \\
5. Authoritarianism & 9 & 11.46 & .85 & .87 \\
6. Sordidness & 5 & 10.01 & .82 & .84 \\
7. Orientation & 7 & 9.78 & .81 & .85 \\
Total & 49 & 78.37 & .83 & .86 \\
\hline
\end{tabular}

As can be seen in Table 2, the internal consistency coefficient $(\alpha)$ was .83 and the composite reliability coefficient was .86 for the 'negative criticism' dimension of the Praetorianistic Behavior Scale; the internal consistency coefficient $(\alpha)$ was .82 and the composite reliability coefficient was .85 for the 'compelling' dimension; the internal consistency coefficient $(\alpha)$ was .84 and the composite reliability coefficient was .89 for the 'restrictiveness ' dimension. The internal consistency coefficient $(\alpha)$ of the 'helpfulness' dimension of the scale was .81 and the composite reliability coefficient was .83; the internal consistency coefficient $(\alpha)$ of .85 for the 'authoritarianism' dimension and the composite reliability coefficient of .87 ; The internal consistency coefficient $(\alpha)$ was .82 for the 'sordidness' dimension and the composite reliability coefficient was .84; the internal consistency coefficient was .81 for the 'orientation' dimension and the composite reliability coefficient was .85 . All of the reliability coefficients for all sub-dimensions of the Praetorianistic Behaviour Scale meet the recommended reliability limit as .70 (Cortina, 1993; Sijtsma, 2009). The total Cronbach's alpha reliability coefficient for the scale was .83 and the composite reliability coefficient was .86. In addition, multicollinearity, endogeneity, and exogeneity problems were not found among the variables included in the scale.

The Confirmatory Factor Analysis (CFA) was conducted on the main application data to confirm the sevenfactor structure of the Praetorianistic Behavior Scale. As a result of the CFA, it was determined that the structural model had a fairly good fit with the measured data $\left(\chi_{(396)}^{2}=786.48 ; \mathrm{p}>0.01\right)$. The result of comparison adaptation indicators also points to a highly conformable model $\left(\chi^{2} / \mathrm{sd}=1.98, \mathrm{p}=0.01, \mathrm{CFI}=0.96, \mathrm{NFI}=0.95, \mathrm{SRMR}=0.05\right.$, RMSEA $=0.05, \mathrm{GFI}=0.94$, AGFI=0.93). The response options of the Praetorianistic Behavior Scale were designed as a five-point Likert type. The items on the Likert type scale are graded as (5)"always" and (1)"never." 


\section{Data Collection}

The scale used in the main application of the research was sent to the schools located in 25 provinces of Ankara by the researcher in person or by e-mail. Participants were asked to fill in the measurement tools within sufficient time by giving information about the research topic. Filled scales were again collected by the researcher or by email channel.

\section{Data Analysis}

The data obtained by the measurement tool were analyzed by SPSS and AMOS program. Before parametric tests were applied, the basic assumptions of these tests were questioned. First, the study group was examined for normal distribution (skewness and kurtosis values). As a result of the normal distribution analysis done in this study, skewness $=-.613$ and kurtosis $=.409$ were found. Since these values were between -1 and +1 , the study group was found to have a normal distribution. In the study group, the homogeneity of variances was examined by Levene test; the significance (p) values in the analysis according to gender, education status, sector, professional tenure and school type variables were higher than .05. Based on these findings, the use of parametric tests was deemed appropriate. When the factors were examined, sphericity tests were performed first, then EFA was made on preliminary application data and CFA was executed on main application data. In order to examine whether the difference between the variables is not only statistically significant but also practical, the magnitude of the effect of meaningful values is also calculated. In this study, the calculation (d) developed by Cohen was used to calculate the effect size (Lakens, 2013). Cohen reports that if the value of $d$ is less than 0.2, the magnitude of the effect is weak, if it is 0.5, it is medium and if it is greater than 0.8, it can be defined as strong (Cohen, 1992). Cohen's d formula (Kotrlik and Williams, 2003) was used to calculate the effect size for the correlation tests. The level of significance in all statistical analyzes was $(\mathrm{p})<0.05$. In the analysis of demographic variables and their relation to dependent variables: a one-way ANOVA was conducted for the professional tenure variable; for gender, educational status, and school type variables were executed by t-test. The Scheffe test was used as a post-hoc test to examine the differences in relational comparisons. All findings were interpreted on the basis of $\mathrm{p}<.05$ level of significance. The following intervals were used to interpret the weighted average scores obtained from the five rating scales used in the study (Harpe, 2015): 4.20 to 5.00 fully (with very high level of praetorianistic behavior), 3.40-4.19 mostly (with high level of praetorianistic behavior), 2.60-3.39 partly (moderately having praetorianistic behavior), 1.80-2.59 little (having low level of praetorianistic behavior), 1.00-1.79 very little (having very low level of praetorianistic behavior).

\section{Findings}

Descriptive statistics of the opinions of the school principals involved in the survey in terms of praetorianistic behavior dimensions are summarized in Table 3.

Table 3. Descriptive statistics of praetorianistic behavior levels of school principals'

\begin{tabular}{llll}
\hline Dimensions & N & $\bar{X}$ & sd \\
\hline 1. Negative criticism & 370 & 3.21 & .63 \\
2. Compelling & 370 & 3.62 & .71 \\
3. Restrictiveness & 370 & 3.16 & .73 \\
4. Helpfulness & 370 & 4.48 & .41 \\
5. Authoritarianism & 370 & 4.12 & .46 \\
6. Sordidness & 370 & 3.79 & .59 \\
7. Orientation & 370 & 3.42 & .57 \\
Total & 370 & 3.68 & .58
\end{tabular}

According to Table 3, the most prevalent and exhibited praetorianistic behavior was identified as 'helpfulness' $(\bar{X}=4.48)$. The standard deviation value $(.41)$ in the dimension of helpfulness shows that the mean value varies between 4.89 and 4.07. This indicates that the school principals showed a great deal of helpfulness. However, it has been found that the authoritarian behavior $(\overline{\mathrm{X}}=4.12 ; \mathrm{sd}=.46)$ is an important praetorianistic behavior exhibited by the school principals. In addition, sordidness $(\overline{\mathrm{X}}=3.79 ; \mathrm{sd}=.59)$ and compelling behavior $(\overline{\mathrm{X}}=3.62 ; \mathrm{sd}=.71)$ were found to be remarkable. Orientation is one of the dimensions of praetorianistic behavior $(\bar{X}=3.42 ; s d=.57)$ that school principals mostly have. School principals, however, were found to have some of the behaviors of 
praetorianism, 'negative criticism' ( $\overline{\mathrm{X}}=3.21$; sd=.63) and 'restrictiveness ' $(\overline{\mathrm{X}}=3.16$; sd=.73) dimensions. Taking into account the aggregate score from the scale, it was determined that the participants displayed high level of praetorianistic behaviors $(\overline{\mathrm{X}}=3.68$; $\mathrm{sd}=.58)$. Findings concerning the praetorianistic behavioral levels of principals according to gender, professional tenure, educational status, sector, and school type in the independent variables of the study are in the following sections.

\section{Findings related to the level of praetorianistic behavior and gender}

The t-test findings for the frequency of school principals exhibiting praetorianistic behavior according to gender are given in Table 4.

Table 4. Differences in praetorianistic behavior levels of school principals' according to gender variable Independent Sample t-test Analysis Results

\begin{tabular}{|c|c|c|c|c|c|c|c|c|}
\hline Dimensions & Gender & $\mathbf{N}$ & $\bar{X}$ & sd & df & $\mathbf{t}$ & $\mathbf{p}$ & Cohen's $d$ \\
\hline \multirow{2}{*}{ Negative Cricitism } & Female & 86 & 3.79 & .48 & \multirow{2}{*}{368} & \multirow{2}{*}{$-13,1$} & \multirow{2}{*}{$.001^{*}$} & \multirow{2}{*}{.38} \\
\hline & Male & 284 & 2.62 & .78 & & & & \\
\hline \multirow{2}{*}{ Compelling } & Female & 86 & 3.95 & .63 & \multirow{2}{*}{368} & \multirow{2}{*}{2.235} & \multirow{2}{*}{$.013^{*}$} & \multirow{2}{*}{.72} \\
\hline & Male & 284 & 3.29 & .79 & & & & \\
\hline \multirow{2}{*}{ Restrictiveness } & Female & 86 & 3.42 & .62 & \multirow{2}{*}{368} & \multirow{2}{*}{$-5,41$} & \multirow{2}{*}{$.039^{*}$} & \multirow{2}{*}{.63} \\
\hline & Male & 284 & 2.89 & .84 & & & & \\
\hline \multirow{2}{*}{ Heplfullness } & Female & 86 & 4.09 & .66 & \multirow{2}{*}{368} & \multirow{2}{*}{2.469} & \multirow{2}{*}{$.007^{*}$} & \multirow{2}{*}{.54} \\
\hline & Male & 284 & 4.83 & .15 & & & & \\
\hline \multirow{2}{*}{ Authoritarianism } & Female & 86 & 4.27 & .31 & \multirow{2}{*}{368} & \multirow{2}{*}{2.152} & \multirow{2}{*}{$.016^{*}$} & \multirow{2}{*}{.47} \\
\hline & Male & 284 & 3.97 & .61 & & & & \\
\hline \multirow{2}{*}{ Sordidness } & Female & 86 & 3.30 & .71 & \multirow[t]{2}{*}{368} & \multirow[t]{2}{*}{2.763} & \multirow[t]{2}{*}{$.003^{*}$} & \multirow[t]{2}{*}{.52} \\
\hline & Male & 284 & 4.28 & .44 & & & & \\
\hline \multirow{2}{*}{ Orientation } & Female & 86 & 3.66 & .42 & \multirow{2}{*}{368} & \multirow{2}{*}{2.021} & \multirow{2}{*}{$.022^{*}$} & \multirow{2}{*}{.38} \\
\hline & Male & 284 & 3.17 & .71 & & & & \\
\hline \multirow{2}{*}{ Praetorianistic Behavior } & Female & 86 & 3.78 & .55 & 368 & 2.104 & $.018^{*}$ & .52 \\
\hline & Male & 284 & 3.58 & .62 & 500 & & & \\
\hline
\end{tabular}

$$
(*) \mathrm{p}<.05
$$

When Table 4 was examined, it was determined that the negative criticism dimension changed significantly according to gender $\left(\mathrm{t}_{(368)}=-13.1, \mathrm{p}<.05\right)$. In the dimension of 'negative criticism' of Praetorianism, women $(\bar{X}=3.79)$ have more negative critical praetorianistic behavior than men $(\bar{X}=3.21)$. Gender, which is the independent variable of the research, modifies the negative criticism behavior moderately $\left(d_{\text {Cohen }}=.38\right)$. Similarly, it was determined that the dimensions of 'compelling', 'restrictiveness', 'helpfulness', 'authoritarianism', 'sordidness' and 'orientation' differ significantly with the genders of school principals $(p<.05)$. While the women principals exhibited more praetorianistic behavior in the dimensions of 'compelling', 'restrictiveness', 'authoritarianism', 'orientation; men showed more of the 'helpfulness' and 'sordidness'. As a result, the behavior of praetorianism changes significantly with gender $\left(\mathrm{t}_{(368)}=2.104, \mathrm{p}<.05\right)$. Praetorianism is more prevalent in women $(\overline{\mathrm{X}}=3.78)$ than in men $(\bar{X}=3.58)$. Gender, the independent variable of the study, effects the behavior of praetorianism moderately $\left(d_{\text {Cohen }}=.52\right)$.

\section{Findings about the levels of praetorianism and professional tenure}

The findings of one-way ANOVA on the behavior of praetorianism according to the professional tenure of school principals are given in Table 5 . 
Table 5. Differences in praetorianistic behavior levels of school principals according to professional tenure variable - One-way ANOVA Analysis Results

\begin{tabular}{|c|c|c|c|c|c|c|c|c|c|}
\hline Dimensions & $\begin{array}{c}\text { Professional } \\
\text { Tenure }\end{array}$ & $\mathbf{N}$ & $\bar{X}$ & sd & df & $\mathbf{F}$ & $\mathbf{p}$ & $\begin{array}{c}\text { Difference } \\
\text { (Scheffe) }\end{array}$ & $\begin{array}{l}\text { Cohen } \\
\text { 's } d\end{array}$ \\
\hline \multirow{3}{*}{ Negative Criticism } & 1. 15 and less & 194 & 3.76 & .37 & \multirow{3}{*}{$\begin{array}{l}2 ; \\
367\end{array}$} & \multirow{3}{*}{5.187} & \multirow{3}{*}{$.006^{*}$} & \multirow{3}{*}{$1-2,1-3,2-3$} & \multirow{3}{*}{.32} \\
\hline & 2. $16-25$ & 134 & 3.16 & .59 & & & & & \\
\hline & 3. 26 and & 42 & 2.71 & .93 & & & & & \\
\hline \multirow{3}{*}{ Compelling } & 1. 15 and less & 194 & 4.11 & .29 & \multirow{3}{*}{$\begin{array}{l}2 ; \\
367\end{array}$} & \multirow{3}{*}{4.006} & \multirow{3}{*}{$.019^{*}$} & \multirow{3}{*}{$1-2,1-3,2-3$} & \multirow{3}{*}{.26} \\
\hline & 2. $16-25$ & 134 & 3.69 & .87 & & & & & \\
\hline & 3. 26 and & 42 & 3.06 & .98 & & & & & \\
\hline \multirow{3}{*}{ Restrictiveness } & 1. 15 and less & 194 & 3.42 & .49 & \multirow{3}{*}{$\begin{array}{l}2 ; \\
367\end{array}$} & \multirow{3}{*}{2.961} & \multirow{3}{*}{.053} & \multirow{3}{*}{-} & \multirow{3}{*}{.03} \\
\hline & 2. $16-25$ & 134 & 3.12 & .68 & & & & & \\
\hline & 3. 26 and & 42 & 2.94 & 1.03 & & & & & \\
\hline \multirow{3}{*}{ Helpfulness } & 1. 15 and less & 194 & 4.17 & .73 & \multirow{3}{*}{$\begin{array}{l}2 ; \\
367\end{array}$} & \multirow{3}{*}{3.856} & \multirow{3}{*}{$.022^{*}$} & \multirow{3}{*}{$1-2,1-3,2-3$} & \multirow{3}{*}{.24} \\
\hline & 2. $16-25$ & 134 & 4.46 & .38 & & & & & \\
\hline & 3. 26 and & 42 & 4.81 & .13 & & & & & \\
\hline \multirow{3}{*}{ Authoritarianism } & 1. 15 and less & 194 & 4.09 & .51 & \multirow{3}{*}{$\begin{array}{l}2 ; \\
367\end{array}$} & \multirow{3}{*}{2.083} & \multirow{3}{*}{.126} & \multirow{3}{*}{-} & \multirow{3}{*}{.09} \\
\hline & 2. $16-25$ & 134 & 4.15 & .46 & & & & & \\
\hline & 3. 26 and & 42 & 4.13 & .41 & & & & & \\
\hline \multirow{3}{*}{ Sordidness } & 1. 15 and less & 194 & 3.86 & .64 & \multirow{3}{*}{$\begin{array}{l}2 ; \\
367\end{array}$} & & & & \\
\hline & 2. $16-25$ & 134 & 3.73 & .55 & & 1.515 & .221 & - & .08 \\
\hline & 3. 26 and & 42 & 3.78 & .58 & & & & & \\
\hline & 1. 15 and less & 194 & 2.59 & 1.06 & & & & & \\
\hline Orientation & 2. $16-25$ & 134 & 3.12 & .46 & $\begin{array}{l}2 ; \\
367\end{array}$ & 3.197 & $.042^{*}$ & $1-2,1-3,2-3$ & .22 \\
\hline & 3. 26 and & 42 & 4.55 & .19 & & & & & \\
\hline & 1. 15 and less & 194 & 3.71 & .58 & & & & & \\
\hline Behavior & 2. $16-25$ & 134 & 3.63 & .56 & $\begin{array}{l}2, \\
367\end{array}$ & 2.693 & .069 & - & .17 \\
\hline & 3. 26 and & 42 & 3.71 & .61 & & & & & \\
\hline
\end{tabular}

(*) $\mathrm{p}<.05$

When Table 5 is examined, it was determined that the 'negative criticism', 'compelling', 'helpfulness' and 'orientation' dimensions of praetorianism differ significantly according to the professional tenure of the school principals $(\mathrm{p}<.05)$. Similarly, it has been determined that participants with professional tenure of 15 years or less in the dimension of compelling exhibited more compelling behavior than other groups. Briefly, the increase in the professional tenure of the participants leads to less praetorianism at the level of negative criticism and compelling dimensions. In sum, it can be concluded that the increase in professional tenure has increased the demonstration of behaviors in the dimensions of helpfulness and orientation of praetorianism. Professional tenure, an independent variable of the research, moderately effects the dimensions of negative criticism, compelling, helpfulness, and orientation of praetorianism $\left(d_{\text {Cohen }}>.20\right)$. However, it has been determined that the dimensions of restrictiveness, authoritarianism, and sordidness did not significantly change with professional tenure ( $\mathrm{p}>.05)$.

\section{Findings related to the level of praetorianistic behaviors and educational status}

The findings of the t-test on the presence of praetorianistic behaviors according to the educational status of the school principals are given in Table 6 . 
Table 6. Differentiation of praetorianistic behavior levels of school principals by educational status variable Independent Sample t-test Analysis Results

\begin{tabular}{|c|c|c|c|c|c|c|c|c|}
\hline Dimensions & $\begin{array}{c}\text { Educational } \\
\text { Status }\end{array}$ & $\mathbf{N}$ & $\bar{X}$ & sd & df & $\mathbf{t}$ & $\mathbf{p}$ & Cohen's $d$ \\
\hline \multirow{2}{*}{ Negative Criticism } & Undergraduate & 291 & 3.66 & .44 & \multirow{2}{*}{368} & \multirow{2}{*}{2.763} & \multirow{2}{*}{$.003^{*}$} & \multirow{2}{*}{.61} \\
\hline & Graduate & 79 & 2.76 & .82 & & & & \\
\hline \multirow{2}{*}{ Compelling } & Undergraduate & 291 & 4.19 & .46 & \multirow{2}{*}{368} & \multirow{2}{*}{2.152} & \multirow{2}{*}{$.016^{*}$} & \multirow{2}{*}{.46} \\
\hline & Graduate & 79 & 3.05 & .96 & & & & \\
\hline \multirow{2}{*}{ Restrictiveness } & Undergraduate & 291 & 3.73 & .41 & \multirow{2}{*}{368} & \multirow{2}{*}{2.469} & \multirow{2}{*}{$.007^{*}$} & \multirow{2}{*}{.52} \\
\hline & Graduate & 79 & 2.59 & .05 & & & & \\
\hline \multirow{2}{*}{ Helpfulness } & Undergraduate & 291 & 4.24 & .64 & \multirow{2}{*}{368} & \multirow{2}{*}{1.575} & \multirow{2}{*}{.058} & \multirow{2}{*}{.68} \\
\hline & Graduate & 79 & 4.72 & .18 & & & & \\
\hline \multirow{2}{*}{ Authoritarianism } & Undergraduate & 291 & 4.38 & .34 & \multirow{2}{*}{368} & \multirow{2}{*}{1.212} & \multirow{2}{*}{.113} & \multirow{2}{*}{.49} \\
\hline & Graduate & 79 & 3.86 & .58 & & & & \\
\hline \multirow{2}{*}{ Sordidness } & Undergraduate & 291 & 3.67 & .79 & \multirow{2}{*}{368} & \multirow{2}{*}{2.178} & \multirow{2}{*}{$.015^{*}$} & \multirow{2}{*}{.47} \\
\hline & Graduate & 79 & 3.91 & .39 & & & & \\
\hline \multirow{2}{*}{ Orientation } & Undergraduate & 291 & 3.05 & .66 & \multirow{2}{*}{368} & \multirow{2}{*}{1.550} & \multirow{2}{*}{.061} & \multirow{2}{*}{.59} \\
\hline & Graduate & 79 & 3.79 & .48 & & & & \\
\hline \multirow{2}{*}{$\begin{array}{l}\text { Praetorianistic } \\
\text { Behavior }\end{array}$} & Undergraduate & 291 & 3.84 & .53 & 368 & 2.152 & $.016^{*}$ & .55 \\
\hline & Graduate & 79 & 3.52 & .63 & 500 & 2.152 & .010 & $.5 J$ \\
\hline
\end{tabular}

(*) $\mathrm{p}<.05$

In Table 6, it was determined that the behavior of praetorianism differed significantly according to the educational status variable $\left(\mathrm{t}_{(368)}=2.152, \mathrm{p}<.05\right)$. Praetorianism behaviors moderately alters the educational status $\left(d_{\text {Cohen }}=.55\right)$. According to this, school principals with undergraduate degrees $(\overline{\mathrm{X}}=3.84)$ have more praetorianistic behaviors than principals with graduate degrees $(\overline{\mathrm{X}}=3.52)$. The 'negative criticism' dimension of the praetorianism varies significantly according to the educational status of the school principals $\left(\mathrm{t}_{(368)}=2.763, \mathrm{p}<.05\right)$. School principals who hold bachelor degree $(\overline{\mathrm{X}}=3.84)$ have more negative attitudes towards praetorianism than principals with a graduate degree $(\overline{\mathrm{X}}=2.76)$. The change in educational status has moderately differentiated behaviors of negative criticism of praetorianism $\left(d_{\text {Cohen }}=.61\right)$. Dimensions of compelling and restrictiveness of praetorianism also differ significantly with the educational status variable. In these dimensions, undergraduates have exhibited more praetorianistic behaviors than graduates. The educational status affects moderately to the dimensions of 'compelling' and 'restrictiveness' ( $\left.d_{\text {Cohen }}<.80\right)$.

\section{Findings regarding the level of praetorianistic behaviors and sector}

The results of the t-test for the presence of praetorianism behaviors according to the sectors in which the school principals work are given in Table 7. 
Table 7. Differentiation of praetorianistic behavior levels of school principals by sector variable - Independent Sample t-test Analysis Results

\begin{tabular}{|c|c|c|c|c|c|c|c|c|}
\hline Dimensions & Sector & $\mathbf{N}$ & $\bar{X}$ & sd & df & $\mathbf{t}$ & $\mathbf{p}$ & Cohen's $d$ \\
\hline \multirow[t]{2}{*}{ Negative Criticism } & Public & 319 & 4.36 & .31 & 368 & 2.763 & $.003^{*}$ & .71 \\
\hline & Private & 51 & 2.06 & .95 & & & & \\
\hline \multirow[t]{2}{*}{ Compelling } & Public & 319 & 4.58 & .11 & 368 & 2.376 & $.009^{*}$ & .63 \\
\hline & Private & 51 & 2.76 & 1.31 & & & & \\
\hline \multirow[t]{2}{*}{ Restrictiveness } & Public & 319 & 3.23 & .77 & 368 & 1.501 & .067 & .14 \\
\hline & Private & 51 & 3.09 & .69 & & & & \\
\hline \multirow[t]{2}{*}{ Helpfulness } & Public & 319 & 4.59 & .32 & 368 & 1.456 & .073 & .11 \\
\hline & Private & 51 & 4.37 & .54 & & & & \\
\hline \multirow[t]{2}{*}{ Authoritarianism } & Public & 319 & 4.15 & .55 & 368 & 1.575 & .058 & .18 \\
\hline & Private & 51 & 4.09 & .37 & & & & \\
\hline \multirow[t]{2}{*}{ Sordidness } & Public & 319 & 2.81 & 1.03 & 368 & 3.112 & $.001^{*}$ & .81 \\
\hline & Private & 51 & 4.77 & .15 & & & & \\
\hline \multirow[t]{2}{*}{ Orientation } & Public & 319 & 4.65 & .18 & 368 & 2.589 & $.005^{*}$ & .66 \\
\hline & Private & 51 & 2.19 & .96 & & & & \\
\hline \multirow[t]{2}{*}{ Praetorianistic Behavior } & Public & 319 & 4.05 & .47 & 368 & $-9,44$ & $.001^{*}$ & .47 \\
\hline & Private & 51 & 3.33 & .69 & & & & \\
\hline
\end{tabular}

(*) $\mathrm{p}<.05$

When Table 7 was examined, it was determined that the behavior of praetorianism changed meaningfully according to the sector variable $\left(\mathrm{t}_{(368)}=1.886, \mathrm{p}<.05\right)$. Sector variable changes moderately the behavior of praetorianism $\left(d_{\text {Cohen }}=.45\right)$. Accordingly, school principals worked in state schools $(\bar{X}=4.05)$ have more praetorianistic behaviors than private schools $(\overline{\mathrm{X}}=3.33)$. It has been determined that the 'sordidness' dimension of the praetorianism has significantly changed according to the working sector of the school principals $\left(\mathrm{t}_{(368)}=3.112\right.$, $\mathrm{p}<.05)$. Sector change affects sordidness behaviors at a high level $\left(d_{\text {Cohen }}>.80\right)$. School principals worked in private schools $(\overline{\mathrm{X}}=4.77)$ exhibit more beneficial praetorian behavior than principals in public schools $(\overline{\mathrm{X}}=2.81)$.

\section{Findings regarding the level of praetorianistic behaviors and school type}

The results of the one-way ANOVA for the behavior of praetorianism according to the type of school attended by the school principals are given in Table 8 . 
Table 8. Differences in praetorianistic behavior attitudes of school principals according to school type variable - One-way ANOVA Analysis Results

\begin{tabular}{|c|c|c|c|c|c|c|c|c|c|}
\hline Dimensions & School Type & $\mathbf{N}$ & $\bar{X}$ & sd & df & $\mathbf{F}$ & $\mathbf{p}$ & $\begin{array}{c}\text { Differenc } \\
\text { e } \\
\text { (Scheffe) }\end{array}$ & $\begin{array}{c}\text { Cohen' } \\
\text { s d }\end{array}$ \\
\hline \multirow{3}{*}{ Negative Criticism } & 1. General & 173 & 2.39 & .82 & \multirow{3}{*}{$\begin{array}{c}2 ; \\
367\end{array}$} & \multirow{3}{*}{5.902} & \multirow{3}{*}{$.003^{*}$} & \multirow{3}{*}{$\begin{array}{c}1-2 ; 1-3 \\
2-3\end{array}$} & \multirow{3}{*}{.46} \\
\hline & 2. Voc. and Tec. & 124 & 3.01 & .68 & & & & & \\
\hline & 3. Religious & 73 & 4.22 & .39 & & & & & \\
\hline \multirow{3}{*}{ Compelling } & 1. General & 173 & 2.45 & 1.1 & \multirow{3}{*}{$\begin{array}{c}2 ; \\
367\end{array}$} & \multirow{3}{*}{5.375} & \multirow{3}{*}{$.005^{*}$} & \multirow{3}{*}{$\begin{array}{c}1-2 ; 1-3 \\
2-3\end{array}$} & \multirow{3}{*}{.41} \\
\hline & 2. Voc. and Tec. & 124 & 3.65 & .77 & & & & & \\
\hline & 3. Religious & 73 & 4.76 & .22 & & & & & \\
\hline \multirow{3}{*}{ Restrictiveness } & 1. General & 173 & 2.54 & 1.03 & \multirow{3}{*}{$\begin{array}{c}2 ; \\
367\end{array}$} & \multirow{3}{*}{5.029} & \multirow{3}{*}{$.007^{*}$} & \multirow{3}{*}{$1-3 ; 2-3$} & \multirow{3}{*}{.37} \\
\hline & 2. Voc. and Tec. & 124 & 2.71 & 1.01 & & & & & \\
\hline & 3. Religious & 73 & 4.23 & .15 & & & & & \\
\hline \multirow{3}{*}{ Helpfulness } & 1. General & 173 & 4.57 & .35 & \multirow{3}{*}{$\begin{array}{c}2 ; \\
367\end{array}$} & \multirow{3}{*}{2.961} & \multirow{3}{*}{.053} & \multirow{3}{*}{ - } & \multirow{3}{*}{.12} \\
\hline & 2. Voc. and Tec. & 124 & 4.69 & .23 & & & & & \\
\hline & 3. Religious & 73 & 4.18 & .65 & & & & & \\
\hline \multirow{3}{*}{ Authoritarianism } & 1. General & 173 & 3.91 & .59 & \multirow{3}{*}{$\begin{array}{c}2 ; \\
367\end{array}$} & \multirow{3}{*}{2.818} & \multirow{3}{*}{.061} & \multirow{3}{*}{-} & \multirow{3}{*}{.09} \\
\hline & 2. Voc. and Tec. & 124 & 4.43 & .31 & & & & & \\
\hline & 3. Religious & 73 & 4.02 & .48 & & & & & \\
\hline \multirow{3}{*}{ Sordidness } & 1. General & 173 & 3.28 & .86 & \multirow{3}{*}{$\begin{array}{c}2 ; \\
367\end{array}$} & & & & \\
\hline & 2. Voc. and Tec. & 124 & 3.83 & .55 & & 4.394 & $.013^{*}$ & $\begin{array}{c}1-2 ; 1-3 \\
2-3\end{array}$ & .33 \\
\hline & 3. Religious & 73 & 4.26 & .36 & & & & & \\
\hline & 1. General & 173 & 3.79 & .53 & & & & & \\
\hline Orientation & 2. Voc. and Tec. & 124 & 3.12 & .62 & $\begin{array}{c}2 ; \\
367\end{array}$ & 2.555 & .079 & - & .06 \\
\hline & 3. Religious & 73 & 3.35 & .56 & & & & & \\
\hline & 1. General & 173 & 3.27 & .76 & & & & & \\
\hline $\begin{array}{l}\text { Praetorianistic } \\
\text { Behavior }\end{array}$ & 2. Voc. and Tec. & 124 & 3.63 & .59 & $\begin{array}{c}2 ; \\
367\end{array}$ & 3.506 & $.031^{*}$ & $\begin{array}{c}1-2 ; 1-3 \\
2-3\end{array}$ & .26 \\
\hline & 3. Religious & 73 & 4.14 & .41 & & & & & \\
\hline
\end{tabular}

$(*) \mathrm{p}<.05$

When Table 8 is examined, the behavior of praetorianism and school type variable differed significantly $\left(\mathrm{F}_{(2 ; 367)}=3.506 ; \mathrm{p}<.05\right)$. School principals working in religious education-based schools $(\overline{\mathrm{X}}=4.14)$ were found to exhibit more praetorianistic behaviors than principals in vocational and technical schools $(\overline{\mathrm{X}}=3.63)$ and in general secondary schools $(\overline{\mathrm{X}}=3.27)$. It was also found that school principals in vocational and technical schools showed more praetorianistic behaviors than principals in general secondary schools. The school-type variable differentiates the behavior of praetorianism in the moderate level $\left(d_{\text {Cohen }}<.80\right)$.

\section{Discussion, Conclusion and Suggestions}

This study aimed to determine the levels of the praetorianistic behaviors of school principals. As a result of the research, it was determined that the most praetorianistic behavior of school principals is 'helpfulness'. They also show, respectively, the behaviors of authoritarianism, sordidness, compelling and orientation. Nevertheless, school principals have partly to do with 'negative criticism' and 'restrictiveness' dimensions of behavior of praetorianism. Again as a result of this study, it has been determined that school principals mostly display praetorianistic behaviors. These findings of the research support the research findings of Ling (2003). However, Cunliffe (2014) reports that praetorianism can be seen as a consequence of Western cultural values and that this praetorianist behavior is learned through a unique social interaction. According to Cunliffe (2014), behaviors such as 
'authoritarianism, negative criticism, compelling, sordidness, and restrictiveness' are the dark side of praetorianism. Ma and Tsui (2015) argue that praetorianism's 'helpfulness and orienteering' dimensions emphasize its Eastern cultural forms and that the concept 'bright side' is at the forefront.

Taking the above-mentioned results of this study into consideration, it has been confirmed that it is possible to show praetorianist features in an organization which continues its activities in a social structure showing praetorianistic tendencies considering the differentiation between eastern and western cultural values (Archer, 1990; Beehner, 2018). Nevertheless, organizations that are significantly influenced by the collectivist structure and the broad power range in Turkish culture make praetorianistic behaviors visible in the business world (Dikili, 2014). As the management models within the organization are influenced by organizational culture, praetorianistic management tendencies can emerge (Güçlü, 2003). As a result, managers are showing close interest to their employees and employees are showing respect and obedience to their leaders. This mutual or symbiotic relationship is evolving to power the manager to force his own authority to his employee (Vural, 2018); ultimately, a cultural leadership approach called praetorianistic leadership arises (Decalo, 1975; Danopoulos \& Zirker, 2002). Taking the results of this study into consideration, it would not be wrong to state that this cultural leadership approach has both negative and positive impacts on organizational governance and functions. The praetorianistic management model cannot be considered as a positive effect on the employee since it is based on establishing a close relationship between the manager and the employee (Giroux, 2018). Thus, employees cannot develop some positive attitudes, such as high job satisfaction and emotional devotion. Based on the assumption that these attitudes will also be reflected in the organizational behavior of employees (Cunliffe, 2014), an increase in employees' performance can be expected. In an environment where employee performance improves, organizational productivity may not be increase. Hence, both the organization and the employees will not reach their goals. Moreover, the repressive, critical and compelling attitudes and behaviors of the manager will cause the increase of the work stress on the employees and the limitation of their freedom (Adams \& Balfour, 2014; Harpe, 2015; Vural, 2018).

Another consequence of this study is that behaviors of praetorianism are differentiated by gender. According to this result, praetorianism is exhibited more in women than men. In the literature, there are different studies supporting this finding. Raviot (2017) and Jarausch (2014) report that women tend to show more praetorianistic behavior than men. But there are conflicting results about gender in literature. Rizvi (2015) and Cunliffe (2014) found that male praetorianistic behaviors were greater than women. Female school principal's having more negative behaviors such as compelling, restrictiveness, authoritarianism, and negative criticism than a man is not only a result of praetorianistic tendencies. Such a result also makes the difference between male and female forms of administration visible. It is also a dilemma that men prefer more helpfulness behaviors compared to women. Ma ve Tsui (2015) report that it has become evident that praetorianism has a bittersweet behavioral pattern in a way that confirms theoretical arguments in the literature as a source of Eastern cultural values. Cunliffe (2014) and Kowalevski (1991) report that this dilemma in western cultures can be seen as a management flaw or illiberal attitude.

In similar to the literature, there is no difference between professional tenure which is one of the independent variables of this study, and praetorianistic behaviors (Raviot, 2017; Cunliffe, 2014; Bowman, 2010). Raviot (2017) argues that managers with fewer professional tenure or fewer managerial experience do not have enough incompany discipline; Cunliffe (2014), on the other hand, reports that executives with more vocational seniority control their employees more. Bowman (2010) argues that the increase in professional tenure does not increase the tendency of the manager to show praetorianistic behaviors, but managers at younger ages are displaying more praetorianistic behavior patterns. According to Bowman (2010), this is due to the fact that young managers do not have the authority to establish authority over older workers or motivate older workers as necessary. In addition, the difference between the educational status of school principals and the praetorianistic behaviors is parallel to the results of various studies in literature (Ma ve Tsui, 2015; Rizvi, 2015; Peruzzotti, 2004). Rizvi (2015) argues that managers at higher education levels have less praetorianistic behaviors; Peruzzotti (2004) reported that managers at lower levels of education had more repressive and rigid management. At this point, the finding that 'undergraduate school managers exhibit more praetorianistic behaviors than graduates' supports the Ma and Tsui's idea (2015) that the 'increase in educational level can create cultural transitions, and in particular transitions from eastern culture to western cultural values'. However, since graduate education is not taken into consideration to be appointed as school principal, many principals are not interested in this education. Although the importance of training at the graduate level and the expertise of science-branch it is well known, these trainings are ignored by 
the educational policy makers. Educational policy makers are constantly changing school management training policies, invalidating school election policy in a widespread and sustainable form. As a result of this study, it is important to find out that the principals working in the public schools display more praetorianistic behaviors than their colleagues working in private schools. This study also examined the relationship between school type and the praetorianistic behaviors of school principals. According to this, it has been found that principals working in schools of religious education show more praetorianistic behaviors than their colleagues in other types of schools. This result of the research shows similarities with the results of research conducted by Catholic schools by Jarausch (2014) and by managers who work in other religious education schools with more praetorianistic behaviors.

As a result of this study determining that behaviors of praetorianism are at a higher level in female school principals have made it clear that female principals are more concerned about their employees and they are also involved in their work and social life. Establishing social contacts with employees and organizing work environments for them includes a proactive management model, but also includes praetorianistic behaviors like intervention and limitations of employees' life and work patterns. Changing behavior in adults is a difficult and time-consuming process, and behavior can be accomplished by external and internal considerations of external pressures and the internal desire for change. One of the important results of this research is to reveal the relationship between school type and praetorianism. It is important that participants in religious education-based schools exhibit more praetorianistic behaviors than those who work in vocational and technical schools and general secondary schools. The fact that principals exhibit praetorianistic behaviors on school, in fact, aims to increase the success or efficiency of the school. It is also the case that principals, who show helpful and orienteering behaviors towards their employees, make working environments more workable. It is the natural flow of life that satisfies the needs of employees and expects similar attitudes and behaviors from the employees of the principals, who show close and warm attention to their employees. However, praetorianism predicts that benefits and interest relations are exchanged in a rather sociological way from normative patterns. In other words, the principle of reciprocity in praetorianism foresees a legitimacy of power based on interests and interests. In addition to the presented debate, this study was conducted within the universe of school principals, and the data presented here was derived directly from the participant's views. Investigations in which third-party observers are used should take into consideration that managers or peer colleagues may be prejudiced because of their ability to lead to praetorianism, tutelage and status quo. Besides, a significant part of the studies on praetorianist behavior in the literature have been carried out in non-educational organizations. it can be stated that there is not enough quantitative and qualitative study in the literature about the praetorianistic behavior forms exhibited by the educational organization principals. For this reason, the frequency with which school principals exhibit praetorianistic behaviors may turn out to be an important theoretical discussion area for future studies. Likewise, there are not enough studies in the literature about the effects of demographic and organizational factors on the praetorianistic behavior patterns of school principals and the causes and consequences of praetorianistic behaviors. In this study, individual and organizational variables such as gender, professional tenure, education status, school type and public-private school discrimination were included in the study. The research is limited to the views of the praetorianism scale of school principals working in public and private high schools in the provinces of Ankara. Social, and economic changes and unexpected situations in the education system may cause to change the views of praetorianism and praetorianistic behaviors, and the research may be invalidated. For this reason, it can be considered as important that the research to be tested with longitudinal studies in different years.

The suggestions developed from the results of this study can be listed as follows:

- Principals who exhibit negative praetorianistic behaviors in order to establish healthy working environments on schools should be made aware of their own behavior. For this purpose, external supervision mechanisms should be provided for the school principals at certain times by organizing 'evaluation by employees', 'selfassessment' or 'performance evaluation' forms.

- Principals should be aware of their own behavior without external pressure or criticism and be empathized with the consequences of their behavior. For this purpose, personal development plans should be prepared to support positive behaviors such as praetorianism, helpfulness and orientation, and to extinguish behaviors that may have adverse effects such as compelling.

- Principals who demonstrate praetorianistic behaviors should be encouraged to take advantage of mentoring and coaching approaches in order to direct them to ideal manager behaviors. 
- Taking these research results into consideration, it may be suggested that school principals should be directed to graduate education. Encouragement of school principals to receive education at the graduate level may be presented as a recommendation to those directing the education policy.

- Negative praetorianistic behavior manifestations of principals working in religious instruction-based schools can be reduced by in-service training or psychosocial development plans for school principals to be organized in these schools. Significant improvement can be achieved with a sustainable development plan. For this purpose, regardless of which school type they work in, an applied communication education covering all school principals and practical education management training can be prepared.

- Extension of this study to take account of the different variables (personality traits, different concepts of organizational behavior, etc.) may be recommended for future research. In future research, it may be advisable to conduct a deeper examination of the qualifications and understanding of qualitative research methods. 

$8(1), 103-137$.

\section{Praetoryanist Davranış Kalıpları: Okul Müdürleri Üzerine Bir İnceleme}

\section{Giriş}

Yönetim bilimleri alanyazınında son elli yıldır doğu ve batı kültürleri arasındaki farklılıklar belirlenmeye çalışılmakta; batının rasyonel gerçekliği ön planda tutan çalışma dinamiklerine karşın doğunun kolektivist gelenekleri incelenmektedir. Doğu ve batı dünyası arasında bir köprü olarak konumlanan ve çalışma yaşamının yapısal özelliklerinin batı tarzında düzenlendiği ülkemizde, toplumsal ve kültürel oluşum doğunun kültürel özelliklerini sergilemektedir (Dikili, 2014). Bu bağlamda batı kaynaklı tasarımların, doğunun sosyal ve kültürel dinamikleriyle uyumlu çalışması kendi içinde belirli güçlükleri beraberinde getirmektedir. Bununla birlikte batı kaynaklı örgüt modelleri ve örgütsel davranış formlarının da Türkiye gibi doğu desenli geleneksel toplumlarda işlerlik kazanması güçleşecektir (Güçlü, 2003). Siyaset biliminin önemli bir kavramı olan ve Ülkemizde de sıklıkla gözlemlenen praetoryanist yönetim anlayışında yönetici veya lider, çalışanın yalnızca iş yaşantısıyla değil, aynı zamanda özel yaşamıyla ilgili konularda çalışanını koşulsuz bir koruma güdüsüyle sahiplenmekte (Nordlinger, 1977) ve onun yaşamında başat rol oynamaktadır (Decalo, 1975). Lider, çalışanın gerek iş ortamında gerekse özel yaşamında refahını sağlamak ve karşılıklı yararı mümkün kılmak için çalışanını kollamaktadır (Danopoulos ve Zirker, 2002). Böylesi bir durumda çalışan da bu ilişkinin karşılığında, yöneticisine saygı, bağlılık ve itaat göstermektedir (Egretau, 2016). Diğer taraftan, batı dünyasında hâkim olan bireyci kültürlerde yönetici veya liderin, astının özel hayatını ilgilendiren konularla ilgilenmesi ve ona karşı sürekli koruyucu bir tutum içinde olması arzu edilen bir durum değildir (Jarausch, 2014). Türkiye'nin de kolektivist bir kültür karakteristiğine sahip olduğu düşünüldüğünde, praetoryanizmin okullarımız için önemli bir kavram olduğu belirlenebilir.

Batı kaynaklı alanyazında praetoryanist okul yönetim modelleri, baskıcı (Rizvi, 2015), antidemokratik (Cunliffe, 2014) ve illiberal (Raviot, 2017; Hansen ve King, 2000) bir durum olarak belirlenirken, doğu kaynaklı çalışmaların praetoryanizmi olumlu bir ilişki biçimi veya karşılıklı yardımseverlik (Ma ve Tsui, 2015), koruyuculuk ve kollayıcılık (Ling, 2003) bağlamında değerlendirdiği görülmektedir. Siyaset bilimi alanyazınında demokrasi karşıtı bir yönetim biçimi olarak tartışılan praetoryanizm (Bowman, 2002; Decalo, 1975), eğitim bilimleri alanyazınında yeni ve güncel bir kavram olarak belirmektedir. Ulaşılan Türk yönetim ve eğitim bilimleri alanyazınında genelde yöneticilerin ve özelde ise okul müdürlerinin praetoryanist davranış özelliklerini inceleyen araştırmalara rastlanmamış olması, bu araştırmanın yürütülmesinde önemli bir güdü kaynağıdır. Bu çalışmada, praetoryanizm kavramı ve eğitim örgütlerinde okul müdürlerinin praetoryanist davranışları sergileme düzeylerine odaklanılmaktadır.

\section{Praetoryanizm Kavramı}

Örgüt yönetimi, örgüt içi siyaset ve güç dengeleri üzerine kuruludur. Örgüt içi siyaset çalışanların birbirleri ile ilişkileri iken, güç dengesi ise bu ilişkinin biçimidir. Örgütteki güç dengesi, literatürde tartışma konusu olmuştur. Siyaset biliminin de önemli kavramlarından biri, örgütteki güç dengesine odaklanan 'praetoryanizm'dir. Praetoryanizm, genel anlamda, bir kişi veya grubun, başka bir birey ya da bireylerin özgürlüklerini hiçe sayarak devlet veya örgüt yönetimine el koymasıdır. Praetoryanizmde iktidarı ele geçiren, yalnızca insanların refahını düşünen ve onları koruma güdüsüyle hareket eden bir güç vardır (Bowman, 2010). Latince "muhafız, lejyoner vb." anlamına gelen praetoryan kelimesi, Roma İmparatorluğu döneminde, imparatoru korumakla görevli özel eğitimli muhafizlara verilen isimdir. Muhafizlar, imparatoru korurken, aynı zamanda ona yaşamsal konularda koşulsuz bir destek sunmaktadırlar. Praetoryanizm kavramı, zamanla dönüşüme uğramış askeri vesayetin devlet organlarını kontrol altına alması anlamında kullanılmıştır. Asker veya sivil bir grubun devlet yönetimini antidemokratik bir biçimde ele geçirmesi veya illiberal demokrasi aygıtı olarak da adlandırılan praetoryanizm, devletin veya bir grubun, vatandaşları korumak ve onlara yardım sağlamak rolünü üstlendiği 'toplumsal refah' düşüncesinin bir sonucu olarak, Roma İmparatorluğu döneminde ortaya çıkmıştır. Esasında Toplumsal refahın sağlanması için devlet, vatandaşlarının yaşam alanlarına müdahale ederek onları sınırlarken, bir yandan da onların yaşamlarını devam ettirmelerine imkân sağlamaktadır (Ben-Eliezer, 1997). Praetoryanizm, koruyucu veya kollayıcı bir muhafız gibi davranarak çevresindekilerin salt iyiliğini gözeten bir kavramdır. Dahası kavram, felsefi olarak başkasının iyiliği için, onun rızası olmadan, onun özgürlüğünün kısıtlayıcı şekilde davranması olarak tanımlanmıştır (Hen-Tov ve Gonzalez, 2011). Praetoryanizm, bir kişinin, kendisi dışındaki insanların iyiliği ya da yararına olabilecek durumlara odaklanarak yaşamlarına müdahil olma, onları yaşamı pahasına koruma ve insanların istek ve düşüncelerini göz ardı ederek çeşitli kararlar alma veya düzenlemelere gitme durumudur (Herspring, 1992). Bu noktada alınan kararlar ve düzenlemeler ile koruma yöntemlerinin, kişi için en doğru seçenek olacağı inancı da praetoryanizm kavramıyla birlikte incelenmektedir. Praetoryanizm, kendisi dışındaki kişileri yetersiz görme ve eleştirmeyi de içermektedir. Praetoryanizmde eleştiri genellikle bir vesayet durumunun 
habercisidir; eleştiri düzeyi arttıkça özgürlüklere müdahale ihtimali de artmaktadır. Başkaları adına, onların iyiliği için koruma eylemini gerekçekleştiren kişi ise praetoryanist (koruyucu); praetoryanistin koruduğunu düşündüğü kişi ise 'pretoryad' (korunan) olarak adlandırılmaktadır (Peruzzotti, 2004).

Kişiler arası ilişkilerde veya örgütsel davranış açısından praetoryanizmden bahsedebilmek için, praetoryanist davranıştan etkilenen bireyin özerk tercihlerinin, eylem ve seçimlerinin engellenmesi gereklidir. Bu noktada praetoryanizm gerek zarardan kaçınma ve gerekse yararlı olma isteğiyle, başka birisinin seçimlerine, istek ve ihtiyaçları ile faaliyetlerine razı olmamak, müdahale etmek ve onu sosyal yaşamdan izole edercesine korumaktır (Archer, 1990). Praetoryanizm literatürde 'koruyucu diktatörlük', 'meşrulaştırılmış güç', 'koruyucu melek', 'askeri vasi' gibi çeşitli kavramlarla ilişkilendirilmektedir. Praetoryanizm, insanlara sıcak fakat gizli niyetlerle yaklaşmak ve bunun onların yararına olacağını hissettirmektir. Bununla birlikte kavram, tamamen yardımsever bir güdü ile, insanları kontrol etme niyetini de içerir (Decalo, 1975). Bu yönüyle praetoryanizm, iktidarı ele geçirmek için başvurulan bir taht oyununa benzemektedir. Praetoryanizmin dayanağını "birey veya grubun zarar görmemesi ya da daha az zarar görmesi niyetiyle, birey veya grup adına yarar sağlayacak şekilde karar alınabilir, kurallar ve sınırlamalar konulabilir ve yönetime el konulabilir" varsayımı oluşturmaktadır (Raviot, 2017). Ancak birey ya da gruplar kendilerine bu şekilde koruyucu ve sınırlayıcı davranılmasını istemedikleri durumlarda, praetoryanist uygulamaların meşruiyeti tartışmalıdır (Nordlinger, 1977). Özellikle askeri darbe sonrası normalleşmeye başlayan kamusal alanlarda praetoryanizm karşıtı eylem ve söylemlere sıklıkla rastlanmaktadır. Günlük hayatta, özel ve kamusal alanda ve çoğunlukla çalışma hayatında praetoryanist uygulama örnekleri sıkça görülebilmektedir. Burada kast edilen askeri vesayet olmasa da her türden vasilik davranışı, eğer yoğun bir koruma içeriyorsa, praetoryanist davranış kalıbı olarak adlandırılır (McLauchlin, 2010). Ayrıca praetoryanizm, siyaset bilimi ve uygulamalı etiğin tartışmalı alanlarından biri olması sebebiyle önemlidir. Bu noktada bireysel özerklik ve onun sınırları, başkalarının kişilik haklarına saygı, başkalarının yararı, kişinin kendi kararlarını alabilme özgürlüğü, özgürlüğün sınırları gibi konular arasında oluşacak gerilimler de önem arz etmektedir (Bowman, 2002).

Askeri ve sivil bir otoritenin, meşru iktidarı ele geçirme çabası olarak ele alındığında praetoryanizm, doğası gereği çeşitli sorunları beraberinde getiren oldukça girift ve tartışmalı bir kavrama dönüşmektedir. Bu noktada, bir taraftan 'yararlı olma' niyeti söz konusuyken diğer taraftan 'baskı, zorlama veya tahakkümü' içermesi, kavramın anlaşılmasını zorlaştırmaktadır (Danopoulos, 1984). Praetoryanist, koruduğu kişinin çıkarlarını, sağlığını, yaşamı veya güvenliğini gözetir ancak, özgürlüklerine ve seçimlerine müdahale eder. Böylece bireyin kısıtlanması meşrulaştırılmaktadır (Adeniran, 1985). Kişilerin kendi kararlarını verme özgürlüğü ile başkalarının yararını gözetme ve koruma sorumluluğu, praetoryanizm kavramının temel çatışma alanıdır. Bununla birlikte kişi kendi yararının veya çıkarının aksine bir tercih yapma veya eylem sergilemede özgür olursa; onun kararlarına müdahil olma durumu, praetoryanizmi akla getirmektedir (Cann ve Danopoulos, 1998). Ancak praetoryanizm yoğun bir koruma davranışı ile birlikte, kişinin temel haklarının bir vasi kontrolüne geçmesine de vurgu yapar. Bunun yanında sosyal sistem içindeki pek çok kişi, fizyolojik veya psikolojik hastalık ve rahatsılıklar, engellilik gibi durumlar ile bireysel seçim yapmaları doğrudan veya dolaylı olarak sınırlı olan kişilerin (tutuklu ve hükümlüler, uyuşturucu kullananlar vb.) özgürlüklerine müdahil olunmasını, onların korunup kollanmasını yani praetoryanizmi haklı görmektedir (Adams ve Balfour, 2014). Burada devletin idaresinin askeri veya sivil bir grup tarafindan ele geçirmesine benzer bir durum söz konusu değildir. Kişi, özgür iradesi ile hareket edecek ve kendini koruyacak bir güce sahip değildir. Ayrıca kişinin yararına olsa bile seçim yapma yeterliği olan kişilerin özgürlüklerinin engellenmesi veya sınırlanmasının haklı görülemeyeceğine ilişkin görüşlerinde praetoryanizm kavramı içinde yer alması dikkat çekicidir. Alanyazındaki söz konusu tartışmalardan hareketle praetoryanizmin felsefi kökenlerinin, öznelerin özgürlüklerini yararcı bir bakış açısıyla kısıtlayabilecek yöntemi (imperium praetoriane) eleştiren Kant'a dayandığı söylenebilir (Baltacı, 2018; Danopoulos ve Zirker, 2002).

Askeri vesayeti daha kolay kabullenen toplumsal yapılarda praetoryanizm, sosyal bir gelenek olarak belirse de batı kültürü içinde yerleşik liberal düşünceye yenik düşmüştür. Bu noktada doğu kültürünün önemli bir parçası olan praetoryanist ilişki biçimi, doğunun kültürel ve toplumsal yapısının kolektivist oluşum biçimi ve geniş güç mesafelerine sahip olmasından kaynaklanan illiberak bir forma sahiptir (Ling, 2003). Batının bireyci kültürel dinamiklerinin olumsuz anlamlar yüklediği ve antidemokratik bir aygıt olarak gördüğü praetoryanist ilişki biçimi, doğu felsefesinin temelinde yer alan Konfüçyüs öğretisinin ana ilkelerinden olan yol göstericilik, otoriteye itaat ve sadakat gibi tutum ve davranışları içermektedir (Kovalewski, 1991). Türk kültürünün de doğu kültürleriyle benzeşim içinde olduğu ve onlar gibi kolektivist bir yapıya ve geniş güç mesafelerine sahip olduğu söylenilebilir. $\mathrm{Bu}$ bakımdan Türk sosyal ve çalışma yaşantısının da praetoryanist ilişsi biçimini benimsediği ifade edilebilir. Batının bireyci toplumsal düzleminde praetoryanizm kavramı, kişilerin hak ve özgürlerini sınırlayan, onların 
yaşam biçimlerine ve özel hayatlarına müdahale eden ve onları kamusal alanda eleştirip yetersiz gören yöneticilerle eş tutulmaktadır. Batı kaynaklı alanyazında olumsuz bir anlam yüklenen praetoryanizm kavramı, koruyucu diktatörlük veya ayrımcılığın gizli ve sinsi bir formu ve otoriter yönetim anlayışı olarak değerlendirilmektedir (Bowman, 2010). Oysa praetoryanizm kavramı cömertlik, iyi niyet, koruma ve kollama gibi otoriterlikle bağdaşmayan davranışları da içermektedir. Bununla birlikte disiplin ve kontrol etkenlerinin batı kaynaklı alanyazında öne çıkarılması, doğu ve batı arasındaki kültürel farklılıklara bağlanmaktadır (Egreteau, 2016).

Praetoryanizm, Türkiye gibi askeri geleneklere bağlı, doğu desenli kolektivist toplum yapılarıyla oldukça uyumlu bir kavramdır. Yöneticinin, çalışanların yaşantılarına müdahil olması, çalışanlara yardımcı olmaya çalışması, onlar adına en iyisi olacağını düşündüğü kararlar alması ve onları ne pahasına olursa olsun koruyup kollaması Türk gelenekleriyle de uyumludur. Ancak özellikle kolektivist kültürlerde son dönemlerde gelişen teknoloji ile birlikte kişilerin bireysel yaşantılara ve bireyciliğe yöneldikleri, bu bağlamda praetoryanizm kavramının içeriğinin değişmeye başladığ 1 belirtilmektedir (Raviot, 2017). İlerleyen bölümde praetoryanizmin davranışının alt boyutları incelenmiştir.

\section{Praetoryanist Davranışının Alt Boyutları}

Praetoryanizm kavramının açıklanabilmesi için bu davranışın altında yatan temel davranış kalıplarının belirlenmesi gereklidir. Alanyazında praetoryanizme ilişkin ilk dönem çalışmalarda kavram, alt boyutları olmayan bir yapıda incelenmiştir. Batı kaynaklı ilk dönem çalışmalarında praetoryanizm, askeri vesayete dayalı otoriter bir yönetim anlayışı olarak görülmüş̧ür. Ancak praetoryanizme ilişkin kavramsal çerçeve tartışmaları doğu kültürünü de içerecek şekilde geliştikçe çeşitli alt boyutlardan bahsedilmeye başlanmıştır. Adams ve Balfour (2014) praetoryanizmi: koruyucu, yardımsever ve totaliter olmak üzere üç alt boyutta incelemişlerdir. Gaub (2017) ise yardımsever, zorlayıcı, yararcı ve çıkarcı praetoryanizm olarak belirlediği dört alt boyutta kavramı incelemiştir. Bunun yanında praetoryanizm kavramı: olumsuz eleştiri, yönlendiricilik ve sınırlayıcılık olarak kavramsallaştırılan üç alt boyutta daha incelenmiş̧ir (Cunliffe, 2014). Bu çalışmada söz konusu boyutlar ana hatlarıly ele alınacaktır.

Olumsuz Eleştiri. İlliberal demokrasinin bir aygıtı olan praetoryanist bağlamda eleştiri, çalışanın potansiyeli ve performansı arasındaki farklılığa vurgu yapan söylemler veya edimler dizgesidir. Çalışanları sürekli olarak olumsuz eleştiren bir örgüt yöneticisi, örgütün amaçlarını gerçekleştirebilmek ve örgüt içi disiplini sağlayabilmenin tek yolunun bu olduğunu düşünmektedir. Eleştirinin, bireyi geliştiren doğasına vurgu yapsa da, çalışanların eksikliklerini ön plana çıkaran olumsuz eleştiriler, bireysel potansiyelin geliştirilmesine imkân tanımamaktadır. Örgüt yöneticisi, çalışanların yaptıkları işleri onlardan daha iyi bildiğini düşünmekte ve bunu çalışanlara hissettirmektedir. İş ortamında gergin bir hava hâkimdir. Yöneticinin, bir çalışanının faaliyetlerini yakından izlemesi veya zaman zaman çalışanlara bir muhafız gibi sert ve kaba davranması bu alt boyuta ilişkin davranışın önemli bir özelliğidir (Baron, 1988).

Zorlayıcılık. Yöneticilerin, yönettiklerine karşı zorlayıcı bir tutum sergilemeleri ve yönetilenleri belli değerleri kabul etmeye zorlamaları olarak ifade edilen zorlayıcılık, kamusal alanın sürekli denetlenmesi ve kamusal alanların yönetim lehine manipüle edilmesidir (Egreteau, 2016). Zorlayıcı praetoryanizmin temelinde yönetimin benimsediği ana akım görüşlerin, yönetilenlerce değiştirilmeden kabul edilmesi yatmaktadır. Yönetilenler, belirli davranışları yapmaya zorlanmakta ve bir süre onların tüm davranışları istendik yönde manipüle edilmekte; böylece yönetilenlerde bir davranış değişikliği sağlanmaktadır. Praetoryanist yönetici genel olarak "Zorlayıcı Diplomasi Stratejisi", uygular. Bu stratejiye göre, demokratik bir örgüt sistemi içerisinde, yönetsel sorumluluğu bulunan karar alıcıya farklı çözüm yöntemleri arasında bir alternatif sunulur. Örgüte yeni katılan veya uyumsuz bir çalışanın, yönetici tarafindan istenen örgütsel değerleri kazanması için belirli düzeyde bir sosyal baskı oluşturulur. Zorlayıcılık, yönlendiriciliğe benzese de aslında tahakkümün görünür bir formudur (Jarausch, 2014).

Sınırlayıcılık. Praetoryanizmin sınırlayıcılık alt boyutunda, yöneticinin çalışanların temel özgürlüklerini gözetse de bu özgürlükleri sınırlama durumu söz konusudur. Sınırlayıcı davranışlar sergileyen yönetici, çalışanlar arasındaki görev dağılımında adil davranmaya çalışır (Alexander, 2001). Sınırlayıcılık yalnızca çalışanın iş ortamlarının kısıtlanmasını değil, aynı zamanda özel hayatının da belli ölçülerde kısıtlanmasını da içerir. Çalışma ortamındaki giyim tarzı, mola süreleri ve izinler, yönetici tarafından sınırlanır. Hatta yönetici, iş arkadaşları arasındaki iletişime de müdahale eder (Hansen ve King, 2000). 
Yardımseverlik, Olumluluk veya İyi Niyetlilik. Praetoryanist bir ilişside tarafların, önceleri genellikle iyi niyetli, olumlu ve yardımsever davranışlar içinde olduğu bilinmektedir. Daha sonra praetoryanist lider, bu olumlu durumu kullanarak tahakkümünü meşru kılar (Maier ve Seligman, 1976). Yardımsever yöneticiler, çalışanların çalışma ve özel yaşamlarında karşılaştıkları sorunları çözmede onlara yardımcı olurlar. Çalışma zamanlarını, iş ortamını ve diğer değişkenleri çalışanların lehine esnetmeye ve çalışanlara karşı cömert ödül ve özendiriciler sunmaya meyillidirler. Bu noktada çalışana gösterilen cömertlik ve özenin arkasındaki motive edici güç, çalışan iyiliğine yönelik bir endişe hali olsa da praetoryanizmde kişinin kontrolü esas olduğundan, yönetici ile çalışan arasında sürekli bir gerginlik söz konusu olabilmektedir. Çalışanlar açısından praetoryanist işverene gösterilen bağlllık, onun samimi cömertliği ve özenine bir karşılık verme yolu olarak görülmekte, çoğu durumda yöneticiden örtük bir şekilde korku veya çekinme tutumu da gözlenmektedir (Seligman, 2005).

Otoriterlik. Otoriter praetoryanist davranış kalıbında yönetici, örgütteki mutlak gücün hâkimidir. Örgüt içi tüm iletişim ve iş süreçleri katı bir şekilde izlenmekte ve sürekli kontrol edilmektedir. Özellikle çalışma ortamlarının görsel kaydediciler (kamera vb.) ile kontrol edilmesi veya işe giriş çıkışların elektronik denetleyicilerle takip edilmesi gibi sınırlayıcı uygulamalar otoriter davranış kalıbının bir sonucudur. Otoriter yönetici, çalışanından kendisine ve örgüte mutlak bağlılık isteme hakkına da sahip olduğunu düşünür. Otoriter praetoryanist davranışlara maruz kalan çalışanların, yöneticilere bağlllığ 1 ve itaati gönülsüz ve iş tatminleri düşüktür. Otoriter praetoryanizm, çalışanların katı çalışma disiplinine uymalarını da zorunlu kılar. Çalışanlar üzerinde kesin otorite ve kontrol sistemi oluşturulmasının nedeni, çalışanların mutlak iyiliğinin düşünüldüğü ve onların sürekli korunması gerektiği varsayımıdır. Otoriter praetoryanist yönetici, kararları tek başına alır; örgüt içi demokratik süreçleri işletmez ve çalışanların sürekli korunması gereken bir acizlik içinde olduğunu düşünür (Altemeye, 1988; Giroux, 2018).

Yönlendiricilik. Preatoryanist yönlendiricilik, literatürde yaygın olarak kullanılan temel alıștırma veya uyum (oryantasyon) kavramlarından farklıdır. Yöneticinin mutlak iradesi ile yürütülen bir yönlendirme söz konusudur. Örgüt yöneticisinin yapılan işlere, alınan kararlara ve örgüt içindeki sosyal süreçlere doğrudan müdahil olması, tüm eylemlerin yürütülmesini kendisinin kontrol etmesi söz konusudur. Yönetici, çalışanların kendi aralarında çözebilecekleri sorunlara müdahale eden ve çatışmaları manipüle eder. Çalışanları kendi istediği doğrultuya yönelten yönetici, çalışanların kariyer gelişimlerine müdahale eder ve onları kendi isteğince yönlendirir. Çalışanlarının kendi belirlediği ilkelere göre çalışmasını isteyen yönetici, örgüt içindeki tüm süreçleri kontrol eder. Yönetici, kendisini çalışanların koruyucusu gibi görürken, çalışanların da kendisine itaat etmesini istemektedir (Gaub, 2017).

Yararcılık veya Çıkarcılık. Yöneticinin işin tamamlanmasıyla ilgili endişesi gereği çalışanlara iyi davranır. Yararcı/Çıkarcı praetoryanist yöneticiler, kendi amaçlarına hizmet edilmesini arzu etmekte ve makyavelist kişilik özellikleri göstermektedirler. Bu özelliğe sahip bireyler, diğer çalışanlarla arasına mesafe koyar ve çalışanların yaptıkları işin sonuçlarına göre hareket ederler. Çalışanları kendi amaçları için kullanmayı severler, içinde bulundukları durumun şartlarına göre hareket ederler. Bu ilişki biçiminde ilkin kazan-kazan stratejisine benzer bir durum söz konusu olsa da sonraları kazanan tarafın yönetici olduğu çalışan tarafından anlaşılmaktadır (Bowman, 2010).

\section{Okul Yönetiminde Praetoryanizm}

Liberal demokrasinin bir gereği olarak karar alma süreçlerinin ve mali hesap verebilirlik mekanizmalarının giderek âdemi merkeziyetçi bir yapıya bürünmesi, okullar arası rekabetin teşvik edilmesi ve okul performansına iliş̧kin tartı̧̧maların yoğunlaşması (Mulford, 2003), öğrenci merkezli ve etik değerler konusunda hassas ve dönüşümcü liderlik özelliklerine haiz praetoryanist müdürlerin öne çıkmasına neden olmuştur. Praetoryanist yönetici davranışlarının gerisinde yatan bireysel ve örgütsel nedenlerin ortaya çıkarılması, praetoryanizmi okullardaki değişme, yenileşme ve girişimcilik faaliyetlerinin öncülü olarak gören araştırmacılar için önemli bir uğraşıya dönüşmüştür (Eyal ve Kark, 2004). Ancak batı toplumlarında, praetoryanizm gibi antidemokratik ve illiberal yönelimler hoş karşılanmamaktadır.

Eğitim Sisteminin giderek karmaşıklaşması, çalışanların uyumunu zorlaştırmaktadır. Böylesi bir karmaşada, çalışanların daha etkili etik değerler gözetilerek yönetilmelerini zorunludur. Okullarda aşırı koruyucu praetoryanist davranışlar ile karşılaşmak olasıdır. Özellikle ilk çocukluk dönemlerindeki okullar, diğer okullara göre daha karmaşık praetoryanist davranışlar sergileyebilmektedir. Okul öncesi eğitim ve ilkokullar, büyük oranda praetoryanist davranış kalıplarına bürünmüş öğretmen ve yöneticileri barındırmaktadırlar. Öğretmenler, okul yöneticileri ve okuldaki diğer çalışanların, çocuğa yönelik praetoryan davranış dizgeleri göstermesinin çıkarcı bir 
praetoryanizmden çok yararcı bir praetoryanizm olarak adlandırılması olasıdır. Bunun yanında okul yöneticilerinin öğretmenler ve diğer çalışanlar üzerinde praetoryanist bir yaklaşım sergilemesi de zorlayıcı, otoriter ve sınırlayıcı praetoryanizmi akla getirmektedir (Beehner, 2018).

Alanyazında özellikle 20. yüzyıl içerisinde okul örgütü ve okul örgütünün yönetimi üzerine yönelik yaklaşımların daha çok teknik, ekonomik ve sosyal sorunları dikkate aldığı, praetoryanizm durumuna ilişkin yönelimin fazla incelenmediği veya farklı kavramlarla karıştırıldığı görülmektedir. Oysa praetoryanizm, siyaset ve yönetim biliminin önemli kavramlarındandır ve sosyal etkisi son derece belirgindir. Buna karşın praetoryanist davranışlar eğitim sistemi içinde yeni değildir. Toplumsal yapının önemli bir parçası olan okullarda praetoryanist davranışlar sıklıkla görülmektedir. Gerek okul yöneticisi gerekse öğretmenlerin farklı türden praetoryanist davranışları, farklı amaçlarla sergilediği bilinmektedir. Türk sosyal bilimler alanyazınında, praetoryanizmi eğitim bilimleri özelinde ele alan bir çalışmaya rastlanılamamıştır. Yine Türk eğitim bilimleri alanyazınında okul müdürlerinin praetoryanist davranışlarının belirlendiği bir araştırma ile karşılaşılmamıştır. Bu bakımdan araştırmanın bu alanda yapılan öncü araştırmalardan biri olacağı düşünülmektedir.

$\mathrm{Bu}$ çalışma okul müdürlerinin görüşlerine göre praetoryanizm davranışının sergilenme durumuna odaklanmaktadır. Çalışma ile yalnızca kamu kurumlarında değil, özel kurumlardaki yöneticilerin görüşleri de araştırmaya dâhil edilmiştir. Bu çalışmanın amacı, okul müdürlerinin praetoryanist davranış biçimlerini gösterme düzeylerini belirlemektir. Ayrıca çalışma ile genelde yönetim bilimleri ve özelde ise eğitim bilimleri alanyazınına farklı ve özgün veriler sunulması ve yeni çalışma alanları açılması da hedeflenmektedir. Araştırmanın ölçülebilir amaçları aşağıda gösterilmektedir:

1. Okul müdürleri praetoryanizm davranışını ne düzeyde göstermektedirler?

2. Okul müdürlerinin praetoryanizmin alt boyutlarına ilişkin görüşleri ile cinsiyet, mesleki kıdem, eğitim durumu, eğitim kolu (sektör) ve görev yapılan okul türü değişkenleri anlamlı bir şekilde farklılaşmakta mıdır?

\section{Yöntem}

\section{Araştırma Modeli}

$\mathrm{Bu}$ araştırma, nicel araştırma paradigması içinde yer alan, betimsel tarama modeli ile tasarlanmıştır. Betimsel tarama modelinde araştırma problemi, kendi bağlamı içinde belirlenmeye çalışılmaktadır. Betimsel tarama modeli, geçmişte ya da halen var olan bir durumu var olduğu şekliyle betimlemeyi amaçlayan araştırma yaklaşımıdır (Vogt, 2006).

\section{Çalışma Grubu}

Ön Uygulama Örneklemi. Bu araştırmada geliştirilen praetoryanist davranış ölçeğinin ana uygulama için kullanılabilir olduğunu belirlemek üzere bir ön uygulama grubu oluşturulmuştur. Ölçeğin ön uygulaması araştırma örnekleminde yer almayan ve Millî Eğitim Bakanlığı İnsan Kaynakları Genel Müdürlüğünün Antalya'da düzenlediği bir hizmet içi eğitim faaliyetine katılan ve basit tesadüfi örnekleme yöntemi ile belirlenen ortaöğretim okul müdürleri üzerinde yürütülmüştür. Ön uygulama kapsamındaki okul müdürleri Trabzon, Rize, Artvin, Ordu, Giresun, Bayburt, Gümüşhane ve Samsun İllerinde görev yapan, örneklemle benzerlik gösteren ve ana uygulamaya katılmayan 159 okul müdüründen oluşmaktadır. Uygulama kapsamında, araştırmacı tarafından okul müdürleri (katılımc1) ile yüz yüze görüşülmüştür. Katılımcılardan ölçekleri doldurmaları istenmiş ve doldurulan ölçekler araştırmacı tarafindan toplanmıştır.

Ana Uygulama Örneklemi. Araştırmanın hedef evrenini, Ankara ilinin 25 ilçesinde resmi ve özel ortaöğretim okullarında görev yapmakta olan 370 okul müdürü oluşturmaktadır. Araştırmada evrenin tamamına ulaşılarak, “tam sayım” tekniği kullanılmıştır. Katılımcılara ilişkin bilgiler Tablo 1’de görülmektedir. 
Tablo 1. Okul müdürlerinin demografik bilgileri

\begin{tabular}{|c|c|c|c|c|}
\hline Değişkenler & Alt Kategoriler & $\mathbf{N}$ & $\%$ & Toplam \\
\hline \multirow{2}{*}{ Cinsiyet } & Kadın & 86 & 23,24 & \multirow{2}{*}{370} \\
\hline & Erkek & 284 & 76,76 & \\
\hline \multirow{3}{*}{ Mesleki Kıdem } & 15 yil ve altı & 194 & 52,43 & \multirow{3}{*}{370} \\
\hline & $16-25$ y1l & 134 & 36,22 & \\
\hline & 26 yıl ve üzeri & 42 & 11,35 & \\
\hline \multirow{2}{*}{ Eğitim Durumu } & Lisans & 291 & 78,65 & \multirow{2}{*}{370} \\
\hline & Lisansüstü & 79 & 21,35 & \\
\hline \multirow{2}{*}{$\begin{array}{l}\text { Eğitim Kolu } \\
\text { (Sektör) }\end{array}$} & Kamu & 319 & 86,22 & \multirow{2}{*}{370} \\
\hline & Özel & 51 & 13,78 & \\
\hline \multirow{3}{*}{ Okul Türü } & Genel Ortaöğretim & 173 & 46,76 & \multirow{3}{*}{370} \\
\hline & Mesleki ve Teknik Ortaöğretim & 124 & 33,51 & \\
\hline & Din Öğretimi & 73 & 19,73 & \\
\hline
\end{tabular}

Tablo 1'e göre katılımcıların \%76,76's1 erkektir ve \%78,65'i lisans seviyesinde eğitime sahiptir. Katılımcıların $\% 52,43$ 'ünün mesleki kıdeminin 15 yıl ve daha az olduğu, ayrıca \%86,22'sinin kamu okullarında görev yaptı̆̆ belirlenmiş̧tir. Katılımcıların \%46,76'sının genel ortaöğretim okullarında (Anadolu lisesi, Fen lisesi, Sosyal Bilimler lisesi), \%33,51'inin mesleki ve teknik ortaöğretim okullarında (Meslek lisesi, Anadolu meslek lisesi, Sağlık Meslek lisesi, Çok Programlı lise, Güzel Sanatlar lisesi, Spor lisesi vb.) ve \%19,73’ünün din öğretimi yapan okullarda (İmam-Hatip lisesi, Anadolu İmam-Hatip lisesi, İmam-Hatip Fen ve Sosyal Bilimler lisesi ve proje okulları) görev yaptıkları belirlenmiştir.

\section{Veri Toplama Aracı}

Araştırmada kullanılan "Praetoryanist Davranış Ölçeği" alanyazındaki ilgili çalışmalardan (Bowman, 2010; McLauchlin, 2010; Jarausch, 2014; Egreteau, 2016; Raviot, 2017; Giroux, 2018) yararlanılarak araştırmacı tarafından geliştirilmiş̧ir. Alanyazında hali hazırda praetoryanist davranış özelliklerini konu edinen bir ölçeğin bulunmadığı belirlenmiştir. Bu durum, araştırmada kullanılmak üzere yeni bir ölçek geliştirilmesini zorunlu hale getirmiştir. Bu noktada araştırmacı tarafindan praetoryanist davranışın tüm alt boyutlarını içerek şekilde bir madde havuzu oluşturulmuş ve bu madde havuzundan 81 maddelik bir taslak ölçek hazırlanmıştır. Hazırlanan 81 maddelik taslak ölçek, 'kapsam geçerliliğini' sağlamak için bilim alanı uzmanlarına sunulmuştur. Kavramın disiplinler arası bir düzlemde olduğu bilindiğinden ölçek ayrıca, 1 sosyolog, 1 psikolog, 3 okul müdürü ve 1 Türk Dil Bilimi alan uzmanlarından oluşan bir gruba daha iletilmiş, alınan dönütlere göre 14 maddenin ölçekten çıkarılmasına karar verilmiştir. Açımlayıcı Faktör Analizi (AFA) faktörleşmeyi belirleyebilmek için yapılmıştır. Bu noktada, Analiz için Kaiser-Meyer-Olkin (KMO) değeri 0,968 ve Barlett's testi anlamlı $(\mathrm{p}<0.01)$ bulunmuştur. Ön uygulama verilerinin faktör analizi için uygun olduğu belirlenmiştir. Daha sonra veri setine açımlayıcı faktör analizi uygulanmıştır. Faktör analizinde bir değişkenin sahip olması gereken en düşük faktör yük değeri .30 olarak önerilmektedir (Sijtsma, 2009). Ölçekten faktör yük değeri .30'dan düşük olan 11 madde ile binişik olan 4 madde çıkarılmışıtır. Açımlayıcı faktör analizinde (AFA), faktörleri oluşturan maddelerin madde toplam korelasyonlarının en az .20 olması önerilmektedir. Buna göre, 3 madde de madde toplam korelasyonu .20'den daha küçük olduğu için çıkarılmıştır. Sonuçta 49 maddenin yedi faktöre dağıldığı ve bu faktörlerin toplam varyansın \%78,37'ini açıkladığı saptanmıştır.

Praetoryanist Davranış Ölçeğinin alt boyutları alanyazındaki tartışmalara uygun olarak isimlendirilmiştir (olumsuz eleştiri, zorlayıcılık, sınırlayıcılık, yardımseverlik, otoriterlik, yararcılık, yönlendiricilik). Olumsuz eleş̧iri boyutu için örnek madde: "Çalışanlara yönelik eleştirilerimin, aslında onların kendilerini gelişstirmesi için bir firsat olduğunu düşünürüm”. Zorlayıcılık boyutu için örnek madde: "Çalı̧̧anlarl, örgütün değerlerine ve kurallarına uymaları konusunda zorlarım". Sınırlayıcılık boyutu için örnek madde: "Çalışanların iş ortamlarında 
istedikleri gibi çalışmalarına izin vermem". Yardımseverlik boyutu için örnek madde: "Çalışanlarımın yaşadı̆̆ maddi ve manevi sorunlarda onlara destek olur, sorunların çözümü için yardımcı olmaya çalışırım”. Otoriterlik boyutu için örnek madde: "Çalışanlarımın emirlerimi koşulsuz yerine getirmelerini beklerim”. Yararcilık boyutu için örnek madde: "Benim yararım, çalışanlarımın yararlarından önce gelir". Yönlendiricilik boyutu için örnek madde: "Çalışanlarımın benim belirlediğim şekilde çalışmaları benim için önemlidir".

Praetoryanist Davranış Ölçeğinin güvenirliği Cronbach's Alfa $(\alpha)$ ve bileşik güvenirlik katsayılarıyla belirlenmiştir. Cronbach's Alfa katsayısında ölçekte yer alan maddelerin faktör yükleri ve hata varyanslarının eşit olduğu; bileşik güvenirlik katsayısındaysa faktör yüklerinin ve hata varyanslarının farklılaştığı durumlarda kullanılması önerilmektedir (Bland ve Altman, 1997). Bu sebeple çok boyutlu ölçeklerin güvenirlik sınamalarında bileşik güvenirlik katsayısı, Cronbach's Alfa katsayısına göre daha dengeli sonuç vermektedir (Rodriguez, Reise ve Haviland, 2016). Bu noktada, her bir faktör için hesaplanan Cronbach's Alfa değerlerine ek olarak bileşik güvenirlik değerlerinin de belirlenmesine karar verilmiştir. Praetoryanizm Ölçeğinin hesaplanan Cronbach's Alfa katsayısı ve doğrulanan Bileşik güvenirlik katsayısı değerleri Tablo 2'de görülmektedir.

Tablo 2. Praetoryanizm ölçeğinin güvenilirlik katsayıları

\begin{tabular}{lcccc}
\hline \multicolumn{1}{c}{ Faktörler } & $\begin{array}{c}\text { Toplam } \\
\text { Madde } \\
\text { Sayısı }\end{array}$ & $\begin{array}{c}\text { Açıklanan } \\
\text { Varyans } \\
\text { Oranı (\%) }\end{array}$ & $\begin{array}{c}\text { Cronbach's } \\
\text { Alfa (o) } \\
\text { Katsayısı }\end{array}$ & $\begin{array}{c}\text { Bileşik } \\
\text { Güvenirlik } \\
\text { Katsayısı }\end{array}$ \\
\hline 1. Olumsuz eleştiri & 7 & 12.26 & .83 & .86 \\
2. Zorlayıcıllk & 8 & 12.13 & .82 & .85 \\
3. Sınırlayıcılık & 7 & 12.28 & .84 & .89 \\
4. Yardımseverlik & 6 & 10.45 & .81 & .83 \\
5. Otoriterlik & 9 & 11.46 & .85 & .87 \\
6. Yararcılık & 5 & 10.01 & .82 & .84 \\
7. Yönlendiricilik & 7 & 9.78 & .81 & .85 \\
Toplam & 49 & 78.37 & .83 & .86 \\
\hline
\end{tabular}

Tablo 2'de inceleneceği üzere, Praetoryanist Davranış Ölçeğinin 'olumsuz eleştiri' boyutu için iç tutarlılık katsayısı $(\alpha) .83$ ve bileşik güvenirlik katsayısı . 86 ; 'zorlayıcılık' boyutu için iç tutarlılık katsayısı $(\alpha) .82$ ve bileşik güvenirlik katsayısı .85 ve 'sınırlayıcılık' boyutu için iç tutarlılık katsayısı $(\alpha) .84$ ve bileşik güvenirlik katsayısı .89 olarak belirlenmiştir. Ölçeğin 'yardımseverlik' boyutunun iç tutarlılık katsayısı $(\alpha) .81$ ve bileşik güvenirlik katsayıs1 .83; 'otoriterlik' boyutu için iç tutarlılık katsayısı $(\alpha) .85$ ve bileşik güvenirlik katsayısı .87; 'yararcılık' boyutu için iç tutarlılık katsayısı $(\alpha) .82$ ve bileşik güvenirlik katsayısı .84 ve 'yönlendiricilik' boyutu için iç tutarlılık katsayısı $(\alpha) .81$ ve bileşik güvenirlik katsayısı .85 olarak belirlenmiştir. Praetoryanist Davranış Ölçeğinin tüm alt boyutları için belirlenen güvenirlik katsayılarının tamamı bir ölçekte bulunması tavsiye edilen güvenirlik sınırı olan .70 (Cortina, 1993; Sijtsma, 2009) şartını karşılaşmaktadır. Ölçeğin tamamına iliş̧kin toplam Cronbach's Alfa güvenirlik katsayısı .83 ve bileşik güvenirlik katsayısı .86 olarak hesaplanmıştır. Ayrıca ölçekte yer alan değişkenler arasında çoklu bağlantılık (multicollinearatiy), içsellik (endogeneity) ve dışsallık (exogeneity) problemine rastlanmamıştır.

Praetoryanist Davranış Ölçeğinin yedi faktörlü yapısını doğrulamak için ana uygulama verileri üzerinde Doğrulayıcı Faktör Analizi (DFA) yapılmıştır. DFA sonucunda, yapısal modelin ölçümlenen verilerle oldukça iyi bir uyuma sahip olduğu belirlenmiştir $\left(\chi_{(396)}^{2}=786.48 ; \mathrm{p}>0.01\right)$. Karşılaştırma uyum göstergelerinin $\mathrm{de}\left(\chi^{2} / \mathrm{sd}=1.98\right.$, $\mathrm{p}=0.01, \mathrm{CFI}=0.96, \mathrm{NFI}=0.95, \mathrm{SRMR}=0.05, \mathrm{RMSEA}=0.05, \mathrm{GFI}=0.94, \mathrm{AGFI}=0.93$ ) oldukça uyumlu bir modeli işaret ettiği sonucuna varılmıştır. Praetoryanist Davranış Ölçeğinin yanıt seçenekleri beşli likert tipi olarak tasarlanmıştır. Likert tipi ölçekte yer alan maddeler: (5) "Her zaman" ve (1) "hiçbir zaman" şeklinde puanlanmaktadır. 


\section{Verilerin Toplanması}

Araştırmanın ana uygulamasında kullanılan ölçek Ankara İlinin 25 ilçesinde yer alan okullara araştırmacı tarafından elden veya e-posta ile ulaştırılmış ve katılımcılara araştırma konusu hakkında bilgi verilerek yeterli süre içinde ölçme araçlarını doldurmaları istenmiştir. Doldurulan ölçekler, yine elden araştırmacı tarafından veya eposta kanalıyla toplanmıştır.

\section{Verilerin Analizi}

Ölçme aracıyla elde edilen veriler, SPSS ve AMOS programıyla analiz edilmiştir. Parametrik testler uygulanmadan önce, bu testlerin temel varsayımları sorgulanmıştır. Öncelikle çalışma grubunun normal dağılım gösterip göstermediği (skewness ve kurtosis değerleri) incelenmiştir. Bu çalışmada yapılan normal dağılım analizleri skewness $($ çarpıklık $)=-.613$; kurtosis $($ basıklık $)=.409$ olarak bulunmuştur. Elde edilen bu değerler -1 ile +1 arasında olduğu için çalışma grubunun normal dağılım gösterdiği bulunmuştur. Parametrik testlerin diğer varsayımı, varyansların homojen olmasıdır. Çalışma grubunun homojenliği Levene testi ile incelenmiş; cinsiyet, eğitim durumu, eğitim kolu (sektör), mesleki kıdem ve okul türü değişkenlerine göre yapılan analizde anlamlılık (p) değerleri .05'ten yüksek çıkmıştır. Elde edilen bu bulgulara dayanarak parametrik testlerin kullanılması uygun görülmüştür. Faktörlerin incelenmesinde öncelikle küresellik testleri yapılmış, ardından ön uygulama verileri üzerinde Açımlayıcı Faktör Analizi (AFA) ve ana uygulama verileri üzerinde Doğrulayıcı Faktör Analizi (DFA) yapılmıştır.

Değişkenler arasındaki farklılığın sadece istatistiksel değil pratikte de anlamlı olup olmadığının incelenmesi amacıyla anlamlı bulunan değerlerin etki büyüklüğü de hesaplanmıştır. Bu çalışmada etki büyüklüğünün hesaplanmasında Cohen tarafından geliştirilen hesaplama (d) kullanılmıştır (Lakens, 2013). Cohen, d değerinin 0.2'den küçük olması durumunda, etki büyüklüğünün zayıf, 0.5 olması durumunda orta ve 0.8 'den büyük olması durumunda ise kuvvetli olarak tanımlanabileceğini bildirmektedir (Cohen, 1992). İlişki testleri için etki büyüklüğü (effect size) hesaplamalarında Cohen's $d$ formülü (Kotrlik ve Williams, 2003) kullanılmıştır. Yapılan istatistiksel analizlerin tümünde anlamlılık düzeyi $(p)<.05$ olarak belirlenmiştir. Demografik değişkenlerin çözümlenmesinde ve bağımlı değiş̧kenlerle olan ilişkilerinin belirlenmesinde: cinsiyet, eğitim durumu ve okul türü değişkenleri için t-testi ile mesleki kıdem değişkeni için tek yönlü varyans analizi yapılmıştır. Cinsiyet, eğitim durumu ve eğitim kolu (sektör) değişkenlerinin, praetoryanizm davranışı ile farklılaşma düzeyi t-testi; mesleki kıdem ve okul türü değişkenleri ise tek yönlü varyans analizi (ANOVA) analizi ile yapılmıştır. İlişkisel karşılaştırmalardaki farklılıkları incelemek için post-hoc testlerinden Scheffe testi kullanılmıştır. Tüm bulgular, $\mathrm{p}<.05$ anlamlılık düzeyi temelinde yorumlanmıştır. Araştırmada kullanılan beşli derecelendirme ölçeklerinden elde edilen ağırlıklı ortalama puanların yorumlanması için aşağıdaki aralıklar kullanılmıştır (Harpe, 2015): 4.20-5.00 çok yükssek (praetoryanist davranışa çok yüksek düzeyde sahip), 3.40-4.19 yüksek (praetoryanist davranışa yüksek düzeyde sahip), 2.60-3.39 orta (praetoryanist davranışa orta düzeyde sahip), 1.80-2.59 düşük (praetoryanist davranışa düşük düzeyde sahip), 1.00-1.79 çok düşük (praetoryanist davranışa çok düşük düzeyde sahip)

\section{Bulgular}

Araştırmaya katılan okul müdürlerinin praetoryanist davranış boyutlarına ilişkin görüşlerinin betimsel istatistikleri Tablo 3 'te özetlenmiştir.

Tablo 3. Okul müdürlerinin praetoryanist davranış düzeylerine ilişkin betimsel istatistikler

\begin{tabular}{lccc}
\hline \multicolumn{1}{c}{ Boyutlar } & N & $\overline{\boldsymbol{X}}$ & SS \\
\hline 1. Olumsuz eleştiri & 370 & 3.21 & .63 \\
2. Zorlayıcılık & 370 & 3.62 & .71 \\
3. Sınırlayıcılık & 370 & 3.16 & .73 \\
4. Yardımseverlik & 370 & 4.48 & .41 \\
5. Otoriterlik & 370 & 4.12 & .46 \\
6. Yararc1lık & 370 & 3.79 & .59 \\
7. Yönlendiricilik & 370 & 3.42 & .57 \\
Toplam & 370 & 3.68 & .58 \\
\hline
\end{tabular}


Tablo 3'e göre okul müdürlerinin en çok sahip oldukları ve sergiledikleri praetoryanist davranış biçimi 'yardımseverlik' ( $\overline{\mathrm{X}}=4.48)$ olarak belirlenmiştir. Yardımseverlik boyutundaki standart sapma değerinin (.41) olması, ortalama değerin 4.89 ile 4.07 değeri arasında değişmekte olduğunu göstermektedir. Bu durum okul müdürlerinin çok yüksek düzeyde yardımseverlik davranışını gösterdiklerini belirlemektedir. Bununla birlikte otoriterlik davranışının ( $\bar{X}=4.12$; ss=.46) okul müdürlerinin sergilediği önemli bir praetoryanist davranış olduğu tespit edilmiştir. Buna ek olarak yararcılık $(\overline{\mathrm{X}}=3.79 ; \mathrm{ss}=.59)$ ve zorlayıcılık $(\overline{\mathrm{X}}=3.62 ; \mathrm{ss}=.71)$ davranışlarının da yüksek düzeylerde olduğu belirlenmiştir. Bu noktada okul müdürleri yönlendiricilik davranışını yüksek düzeyde göstermektedir denilebilir ( $\bar{X}=3.42$; ss=.57). Ancak katılımcıların, praetoryanizmin 'olumsuz eleştiri' $(\overline{\mathrm{X}}=3.21$; ss=.63) ile 'sınırlayıcılık' ( $\bar{X}=3.16 ; \mathrm{ss}=.73$ ) boyutlarındaki davranışlara orta düzeyde sahip oldukları belirlenmiştir. Ölçekten alınan toplan puan dikkate alındığında katılımcıların, yüksek düzeyde praetoryanist davranışlar içinde olduğu belirlenmiştir ( $\bar{X}=3.68$; ss=.58). Araştırmanın bağımsız değişkenleri konumundaki cinsiyet, mesleki kıdem, eğitim durumu, eğitim kolu (sektör) ve okul türüne göre katılımcıların praetoryanist davranış düzeylerine ilişkin bulgular ilerleyen bölümlerde yer almaktadır.

\section{Praetoryanist davranış düzeyleri ile cinsiyet değişkenine ilişkin bulgular}

Okul müdürlerinin cinsiyete göre praetoryanizm davranışlarını sergileme sıklıklarına ilişkin t-testi sonuçları Tablo 4'te verilmiştir.

Tablo 4. Okul müdürlerinin praetoryanist davranış düzeylerinin cinsiyet değişkenine göre farklılaşması Bağımsız Örneklem t-testi Analiz Sonuçları

\begin{tabular}{|c|c|c|c|c|c|c|c|c|}
\hline Boyutlar & Cinsiyet & $\mathbf{N}$ & $\bar{X}$ & $\mathbf{S}$ & sd & $\mathbf{t}$ & $\mathbf{p}$ & Cohen's $d$ \\
\hline \multirow{2}{*}{ Olumsuz eleştiri } & Kadın & 86 & 3.79 & .48 & \multirow{2}{*}{368} & \multirow{2}{*}{$-13,1$} & \multirow{2}{*}{$.031^{*}$} & \multirow{2}{*}{.38} \\
\hline & Erkek & 284 & 2.62 & .78 & & & & \\
\hline \multirow{2}{*}{ Zorlayıcılık } & Kadın & 86 & 3.95 & .63 & \multirow{2}{*}{368} & \multirow{2}{*}{2.235} & \multirow{2}{*}{$.013^{*}$} & \multirow{2}{*}{.72} \\
\hline & Erkek & 284 & 3.29 & .79 & & & & \\
\hline \multirow{2}{*}{ Sınırlayıcılık } & Kadın & 86 & 3.42 & .62 & \multirow{2}{*}{368} & \multirow{2}{*}{$-5,41$} & \multirow{2}{*}{$.039^{*}$} & \multirow{2}{*}{.63} \\
\hline & Erkek & 284 & 2.89 & .84 & & & & \\
\hline \multirow{2}{*}{ Yardımseverlik } & Kadın & 86 & 4.09 & .66 & \multirow{2}{*}{368} & \multirow{2}{*}{2.469} & \multirow{2}{*}{$.007^{*}$} & \multirow{2}{*}{.54} \\
\hline & Erkek & 284 & 4.83 & .15 & & & & \\
\hline \multirow{2}{*}{ Otoriterlik } & Kadın & 86 & 4.27 & .31 & \multirow{2}{*}{368} & \multirow{2}{*}{2.152} & \multirow{2}{*}{$.016^{*}$} & \multirow{2}{*}{.47} \\
\hline & Erkek & 284 & 3.97 & .61 & & & & \\
\hline \multirow{2}{*}{ Yararcılık } & Kadın & 86 & 3.30 & .71 & \multirow{2}{*}{368} & \multirow{2}{*}{2.763} & \multirow{2}{*}{$.003^{*}$} & \multirow{2}{*}{.52} \\
\hline & Erkek & 284 & 4.28 & .44 & & & & \\
\hline \multirow{2}{*}{ Yönlendiricilik } & Kadın & 86 & 3.66 & .42 & \multirow{2}{*}{368} & \multirow{2}{*}{2.021} & \multirow{2}{*}{$.022^{*}$} & \multirow{2}{*}{.38} \\
\hline & Erkek & 284 & 3.17 & .71 & & & & \\
\hline \multirow{2}{*}{ Praetoryanizm Davranışı } & Kadın & 86 & 3.78 & .55 & 368 & 2.104 & $018^{*}$ & 52 \\
\hline & Erkek & 284 & 3.58 & .62 & 300 & 2.104 & & \\
\hline
\end{tabular}

(*) $\mathrm{p}<.05$

Tablo 4 incelendiğinde, olumsuz eleştiri boyutunun cinsiyete göre anlamlı bir şekilde değiştiği belirlenmiştir $\left(\mathrm{t}_{(368)}=-13,1, \mathrm{p}<.05\right)$. Praetoryanizmin 'olumsuz eleştiri' boyutunda kadınlar $(\overline{\mathrm{X}}=3.79)$, erkeklere göre $(\overline{\mathrm{X}}=3.21)$ daha fazla oranda olumsuz eleştirel praetoryanist davranışlara sahiptirler. Araştırmanın bağımsız değişkeni olan cinsiyet, olumsuz eleştiri davranışını $\left(d_{\text {Cohen }}=.38\right)$ orta düzeyde farklılaştırmaktadır. Benzer şekilde 'zorlayıcılık', 'sınırlayıcılık', 'yardımseverlik', 'otoriterlik', 'yararcılık' ve 'yönlendiricilik' boyutlarının da okul müdürlerinin cinsiyetleriyle anlamlı bir şekilde farklılaştığı belirlenmiştir $(p<.05)$. Bununla birlikte 'zorlayıcılık', 'sınırlandırıcılık', 'otoriterlik', 'yönlendiricilik' boyutlarında okul müdürleri daha fazla praetoryanist davranışlar sergilemekteyken; erkekler, praetoryanizmin 'yardımseverlik' ve 'yararcılık' boyutlarındaki davranışları daha fazla göstermektedirler. Praetoryanizm davranışını kadınlar $(\overline{\mathrm{X}}=3.78)$, erkeklere göre $(\overline{\mathrm{X}}=3.58)$ daha fazla 
sergilemektedirler. Araştırmanın bağımsız değişkeni olan cinsiyet, praetoryanizm davranışlarını $\left(d_{\text {Cohen }}=.52\right)$ orta düzeyde farklılaştırmaktadır.

\section{Praetoryanist davranış düzeyleri ile mesleki kıdem değişkenine iliş̧in bulgular}

Okul müdürlerinin mesleki kıdemlerine göre praetoryanizm davranışlarına ilişkin tek yönlü varyans analizi sonuçları Tablo 5'te verilmiştir.

Tablo 5. Okul müdürlerinin praetoryanist davranış düzeylerinin mesleki kıdem değişkenini göre farklılaşması - Tek Yönlü Varyans (ANOVA) Analiz Sonuçları

\begin{tabular}{|c|c|c|c|c|c|c|c|c|c|}
\hline Boyutlar & Mesleki Kıdem & $\mathbf{N}$ & $\bar{X}$ & $\mathbf{S}$ & sd & $\mathbf{F}$ & $\mathbf{p}$ & $\begin{array}{c}\text { Anlamlı Fark } \\
\text { (Schoffe) }\end{array}$ & $\begin{array}{l}\text { Cohe } \\
\text { n's } d \\
\end{array}$ \\
\hline \multirow{3}{*}{ Olumsuz eleştiri } & 1. 15 y1l ve alt1 & 194 & 3.76 & .37 & \multirow{3}{*}{$\begin{array}{c}2 ; \\
367\end{array}$} & \multirow{3}{*}{5.187} & \multirow{3}{*}{$.006^{*}$} & \multirow{3}{*}{$1-2,1-3,2-3$} & \multirow{3}{*}{.32} \\
\hline & 2. $16-25 \mathrm{y} 11$ & 134 & 3.16 & .59 & & & & & \\
\hline & 3. 26 y1l ve üzeri & 42 & 2.71 & .93 & & & & & \\
\hline \multirow{3}{*}{ Zorlayıcılık } & 1. 15 y1l ve alt & 194 & 4.11 & .29 & \multirow{3}{*}{$\begin{array}{c}2 ; \\
367\end{array}$} & \multirow{3}{*}{4.006} & \multirow{3}{*}{$.019^{*}$} & \multirow{3}{*}{$1-2,1-3,2-3$} & \multirow{3}{*}{.26} \\
\hline & 2. $16-25$ y1l & 134 & 3.69 & .87 & & & & & \\
\hline & 3. 26 yıl ve üzeri & 42 & 3.06 & .98 & & & & & \\
\hline \multirow{3}{*}{ Sinırlayıcılık } & 1. 15 y1l ve alt 1 & 194 & 3.42 & .49 & \multirow{3}{*}{$\begin{array}{c}2 ; \\
367\end{array}$} & \multirow{3}{*}{2.961} & \multirow{3}{*}{.053} & \multirow{3}{*}{-} & \multirow{3}{*}{.03} \\
\hline & 2. $16-25$ y1l & 134 & 3.12 & .68 & & & & & \\
\hline & 3. 26 yil ve üzeri & 42 & 2.94 & 1.03 & & & & & \\
\hline \multirow{3}{*}{ Yardımseverlik } & 1. 15 y1l ve alt 1 & 194 & 4.17 & .73 & \multirow{3}{*}{$\begin{array}{c}2 \\
367\end{array}$} & \multirow{3}{*}{3.856} & \multirow{3}{*}{$.022^{*}$} & \multirow{3}{*}{$1-2,1-3,2-3$} & \multirow{3}{*}{.24} \\
\hline & 2. $16-25 \mathrm{y} 11$ & 134 & 4.46 & .38 & & & & & \\
\hline & 3. 26 y1l ve üzeri & 42 & 4.81 & .13 & & & & & \\
\hline \multirow{3}{*}{ Otoriterlik } & 1. 15 y1l ve altı & 194 & 4.09 & .51 & \multirow{3}{*}{$\begin{array}{c}2 ; \\
367\end{array}$} & \multirow{3}{*}{2.083} & \multirow{3}{*}{.126} & \multirow{3}{*}{-} & \multirow{3}{*}{.09} \\
\hline & 2. $16-25 \mathrm{y} 1 \mathrm{l}$ & 134 & 4.15 & .46 & & & & & \\
\hline & 3. 26 yil ve üzeri & 42 & 4.13 & .41 & & & & & \\
\hline \multirow{3}{*}{ Yararcılık } & 1. 15 y1l ve alt 1 & 194 & 3.86 & .64 & \multirow{3}{*}{$\begin{array}{c}2 ; \\
367\end{array}$} & & & & \\
\hline & 2. $16-25 \mathrm{y} 1 \mathrm{l}$ & 134 & 3.73 & .55 & & 1.515 & .221 & - & .08 \\
\hline & 3. 26 yıl ve üzeri & 42 & 3.78 & .58 & & & & & \\
\hline & 1. 15 y1l ve alt 1 & 194 & 2.59 & 1.06 & & & & & \\
\hline Yönlendiricilik & 2. $16-25 \mathrm{y} 1 \mathrm{l}$ & 134 & 3.12 & .46 & $\begin{array}{c}2 ; \\
367\end{array}$ & 3.197 & $.042^{*}$ & $1-2,1-3,2-3$ & .22 \\
\hline & 3. 26 yil ve üzeri & 42 & 4.55 & .19 & & & & & \\
\hline Praetoryanizm & 1. 15 y1l ve altı & 194 & 3.71 & .58 & $2:$ & & & & \\
\hline Davranışı & 2. $16-25$ y1l & 134 & 3.63 & .56 & 367 & 2.693 & .069 & - & .17 \\
\hline & 3. 26 yil ve üzeri & 42 & 3.71 & .61 & & & & & \\
\hline
\end{tabular}

$(*) \mathrm{p}<.05$

Tablo 5 incelendiğinde, praetoryanizm davranışının 'olumsuz eleştiri', 'zorlayıcılık', 'yardımseverlik' ve 'yönlendiricilik' boyutlarının, okul müdürlerinin mesleki kıdemine göre anlamlı bir şekilde farklılaştığı belirlenmiştir $(\mathrm{p}<.05)$. Benzer şekilde zorlayıcılık boyutunda mesleki kıdemi 15 yıl ve daha az olan katılımcıların, diğer mesleki kıdem gruplarına göre daha fazla zorlayıcı davranışlar sergiledikleri belirlenmiştir. Araştırmanın bağımsız değişkeni olan mesleki kıdem, praetoryanizm davranışının olumsuz eleştiri, zorlayıcılık, yardımseverlik ve yönlendiricilik boyutlarını $\left(d_{\text {Cohen }}>\right.$.20) orta düzeyde farklılaştırmaktadır. Ancak sınırlayıcılık, otoriterlik ve yararcılık boyutlarının, mesleki kıdem ile anlamlı bir şekilde değişmediği belirlenmiştir ( $\mathrm{p}>.05)$.

\section{Praetoryanist davranış düzeyleri ile eğitim durumu değişkenine ilişkin bulgular}

Okul müdürlerinin eğitim durumuna göre praetoryanist davranışlara sahip olma durumlarına ilişkin t-testi sonuçları Tablo 6'da verilmiştir. 
Tablo 6. Okul müdürlerinin praetoryanist davranış düzeylerinin eğitim durumu değişkenine göre farklılaşması Bağımsız Örneklem t-testi Analiz Sonuçları

\begin{tabular}{|c|c|c|c|c|c|c|c|c|}
\hline Boyut & $\begin{array}{c}\text { Eğitim } \\
\text { Durumu }\end{array}$ & $\mathbf{N}$ & $\bar{X}$ & $\mathbf{s}$ & sd & $\mathbf{t}$ & $\mathbf{p}$ & Cohen's $d$ \\
\hline \multirow{2}{*}{ Olumsuz eleştiri } & Lisans & 291 & 3.66 & .44 & \multirow{2}{*}{368} & \multirow{2}{*}{2.763} & \multirow{2}{*}{$.003^{*}$} & \multirow{2}{*}{.61} \\
\hline & Lisansüstü & 79 & 2.76 & .82 & & & & \\
\hline \multirow{2}{*}{ Zorlayıcılık } & Lisans & 291 & 4.19 & .46 & \multirow{2}{*}{368} & \multirow{2}{*}{2.152} & \multirow{2}{*}{$.016^{*}$} & \multirow{2}{*}{.46} \\
\hline & Lisansüstü & 79 & 3.05 & .96 & & & & \\
\hline \multirow[t]{2}{*}{ Sinırlayıcılık } & Lisans & 291 & 3.73 & .41 & \multirow{2}{*}{368} & \multirow{2}{*}{2.469} & \multirow{2}{*}{$.007^{*}$} & \multirow{2}{*}{.52} \\
\hline & Lisansüstü & 79 & 2.59 & .05 & & & & \\
\hline \multirow{2}{*}{ Yardımseverlik } & Lisans & 291 & 4.24 & .64 & \multirow{2}{*}{368} & \multirow{2}{*}{1.575} & \multirow{2}{*}{.058} & \multirow{2}{*}{.68} \\
\hline & Lisansüstü & 79 & 4.72 & .18 & & & & \\
\hline \multirow{2}{*}{ Otoriterlik } & Lisans & 291 & 4.38 & .34 & \multirow{2}{*}{368} & \multirow{2}{*}{1.212} & \multirow{2}{*}{.113} & \multirow{2}{*}{.49} \\
\hline & Lisansüstü & 79 & 3.86 & .58 & & & & \\
\hline \multirow{2}{*}{ Yararcılık } & Lisans & 291 & 3.67 & .79 & \multirow{2}{*}{368} & \multirow{2}{*}{2.178} & \multirow{2}{*}{$.015^{*}$} & \multirow{2}{*}{.47} \\
\hline & Lisansüstü & 79 & 3.91 & .39 & & & & \\
\hline \multirow{2}{*}{ Yönlendiricilik } & Lisans & 291 & 3.05 & .66 & \multirow{2}{*}{368} & \multirow{2}{*}{1.550} & \multirow{2}{*}{.061} & \multirow[t]{2}{*}{.59} \\
\hline & Lisansüstü & 79 & 3.79 & .48 & & & & \\
\hline \multirow{2}{*}{$\begin{array}{l}\text { Praetoryanizm } \\
\text { Davranış1 }\end{array}$} & Lisans & 291 & 3.84 & .53 & 368 & 2.152 & $.016^{*}$ & .55 \\
\hline & Lisansüstü & 79 & 3.52 & .63 & & & & \\
\hline
\end{tabular}

$(*) \mathrm{p}<.05$

Tablo 6'da praetoryanizm davranışının eğitim durumu değişkenine göre anlamlı bir şekilde farklılaştığ belirlenmiştir $\left(\mathrm{t}_{(368)}=2.152, \mathrm{p}<.05\right)$. Praetoryanizm davranışı eğitim durumu değişkenine göre orta düzeyde farklılaştırmaktadır $\left(d_{\text {Cohen }}=.55\right)$. Buna göre lisans mezunu okul müdürleri $(\bar{X}=3.84)$, lisansüstü mezuniyet derecesine sahip olanlara göre $(\bar{X}=3.52)$ daha fazla praetoryanist davranışlara sahiptirler. Praetoryanizmin 'olumsuz eleştiri' boyutu, okul müdürlerinin eğitim durumuna göre anlamlı olarak değişmektedir $\left(\mathrm{t}_{(368)}=2.763\right.$, $\mathrm{p}<.05)$. Lisans düzeyinde mezun olan okul müdürleri $(\bar{X}=3.84)$, lisansüstü mezuniyet derecesine sahip olanlara göre $(\overline{\mathrm{X}}=2.76)$ praetoryanizmin olumsuz eleştiri boyutundaki davranışlara daha fazla sahiptirler. Eğitim Durumu değişkeni, praetoryanizmin olumsuz eleştiri boyutundaki davranışları orta düzeyde etkilemektedir $\left(d_{\text {Cohen }}=.61\right)$. Praetoryanizmin 'zorlayıcılık' ve 'sınırlayıcılık' boyutları da eğitim durumu değişkeniyle anlamlı bir şekilde farklılaşmaktadır. Anılan boyutlarda lisans düzeyinde mezuniyet derecesine sahip okul müdürleri, lisansüstü mezuniyet derecesine sahip olanlara göre daha fazla praetoryanist davranışlara sahiptirler. Eğitim durumu değişkeni 'zorlayıcılık' ve 'sınırlayıcılık' boyutlarını orta düzeyde etkilemektedir $\left(d_{\text {Cohen }}<.80\right)$.

\subsection{Praetoryanist davranış düzeyleri ile eğitim kolu (sektör) değişkenine ilişkin bulgular}

Okul müdürlerinin görev yaptıkları eğitim koluna (sektör) göre praetoryanizm davranışlarına sahip olma durumlarına ilişkin t-testi sonuçları Tablo 7'de verilmiştir. 
Tablo 7. Okul müdürlerinin praetoryanist davranış düzeylerinin eğitim kolu (sektör) değişkenine göre farklılaşması - Bağımsız Örneklem t-testi Analiz Sonuçları

\begin{tabular}{|c|c|c|c|c|c|c|c|c|}
\hline Boyut & $\begin{array}{c}\text { Eğitim } \\
\text { Kolu }\end{array}$ & $\mathbf{N}$ & $\bar{X}$ & SS & sd & $\mathbf{t}$ & $\mathbf{p}$ & Cohen's $d$ \\
\hline \multirow{2}{*}{ Olumsuz eleştiri } & Kamu & 319 & 4.36 & .31 & \multirow{2}{*}{368} & \multirow{2}{*}{2.763} & \multirow{2}{*}{$.003^{*}$} & \multirow{2}{*}{.71} \\
\hline & Özel & 51 & 2.06 & .95 & & & & \\
\hline \multirow{2}{*}{ Zorlayıcılık } & Kamu & 319 & 4.58 & .11 & \multirow{2}{*}{368} & \multirow{2}{*}{2.376} & \multirow{2}{*}{$.009^{*}$} & \multirow{2}{*}{.63} \\
\hline & Özel & 51 & 2.76 & 1.31 & & & & \\
\hline \multirow{2}{*}{ Sinırlayıcılık } & Kamu & 319 & 3.23 & .77 & \multirow{2}{*}{368} & \multirow{2}{*}{1.501} & \multirow{2}{*}{.067} & \multirow{2}{*}{.14} \\
\hline & Özel & 51 & 3.09 & .69 & & & & \\
\hline \multirow{2}{*}{ Yardımseverlik } & Kamu & 319 & 4.59 & .32 & \multirow{2}{*}{368} & \multirow{2}{*}{1.456} & \multirow{2}{*}{.073} & \multirow{2}{*}{.11} \\
\hline & Özel & 51 & 4.37 & .54 & & & & \\
\hline \multirow{2}{*}{ Otoriterlik } & Kamu & 319 & 4.15 & .55 & \multirow{2}{*}{368} & \multirow{2}{*}{1.575} & \multirow{2}{*}{.058} & \multirow{2}{*}{.18} \\
\hline & Özel & 51 & 4.09 & .37 & & & & \\
\hline \multirow{2}{*}{ Yararcılık } & Kamu & 319 & 2.81 & 1.03 & \multirow{2}{*}{368} & \multirow{2}{*}{3.112} & \multirow{2}{*}{$.001^{*}$} & \multirow{2}{*}{.81} \\
\hline & Özel & 51 & 4.77 & .15 & & & & \\
\hline \multirow{2}{*}{ Yönlendiricilik } & Kamu & 319 & 4.65 & .18 & \multirow{2}{*}{368} & \multirow{2}{*}{2.589} & \multirow{2}{*}{$.005^{*}$} & \multirow{2}{*}{.66} \\
\hline & Özel & 51 & 2.19 & .96 & & & & \\
\hline Praetoryanizm & Kamu & 319 & 4.05 & .47 & \multirow{2}{*}{368} & $-9,44$ & $.001^{*}$ & .47 \\
\hline Davranışı & Özel & 51 & 3.33 & .69 & & $-5,+4$ & & .41 \\
\hline
\end{tabular}

(*) $\mathrm{p}<.05$

Tablo 7 incelendiğinde praetoryanizm davranışının, eğitim kolu (sektör) değişkenine göre anlamı bir şekilde farklılaştığ1 belirlenmiştir $\left(\mathrm{t}_{(368)}=1.886, \mathrm{p}<.05 ; d_{\text {Cohen }}=.45\right)$. Buna göre kamu okullarında görev yapan okul müdürleri ( $\overline{\mathrm{X}}=4.05)$, özel okullarda görev yapanlara göre $(\overline{\mathrm{X}}=3.33)$ daha yüksek düzeyde praetoryanist davranışlara sahiptirler. Praetoryanizmin 'yararcılık' boyutunun okul müdürlerinin görev yaptığı eğitim koluna göre anlamlı bir şekilde değiştiği belirlenmiştir $\left(\mathrm{t}_{(368)}=3.112, \mathrm{p}<.05\right)$. Eğitim kolu değişkeni, yararc1 praetoryanist davranışları yüksek düzeyde etkilemektedir $\left(d_{\text {Cohen }}>.80\right)$. Özel okullarda çalışan okul müdürleri $(\overline{\mathrm{X}}=4.77), \mathrm{kamu}$ okullarında çalışanlaragöre $(\overline{\mathrm{X}}=2.81)$ daha fazla yararcı praetoryanist davranışlar sergilemektedirler.

\section{Praetoryanist davranış düzeyleri ile okul türü değişkenine ilişkin bulgular}

Okul müdürlerinin görev yaptıkları okul türüne göre praetoryanizm davranışlarına ilişkin tek yönlü varyans analizi sonuçları Tablo 8'de verilmiştir. 
Tablo 8. Okul müdürlerinin praetoryanist davranış düzeylerinin okul türü değişkenini göre farklılaşması - Tek Yönlü Varyans (ANOVA) Analiz Sonuçları

\begin{tabular}{|c|c|c|c|c|c|c|c|c|c|}
\hline Boyutlar & Okul Türü & $\mathbf{N}$ & $\bar{X}$ & ss & sd & $\mathbf{F}$ & $\mathbf{p}$ & $\begin{array}{c}\text { Anlaml } \\
\text { Fark }\end{array}$ & $\begin{array}{c}\text { Cohen's } \\
d\end{array}$ \\
\hline \multirow{3}{*}{$\begin{array}{l}\text { Olumsuz } \\
\text { eleştiri }\end{array}$} & 1. Genel Ort. & 173 & 2.39 & .82 & \multirow{3}{*}{$\begin{array}{c}2 ; \\
367\end{array}$} & \multirow{3}{*}{5.902} & \multirow{3}{*}{$.003^{*}$} & \multirow{3}{*}{$\begin{array}{c}1-2 ; 1-3 \\
2-3\end{array}$} & \multirow{3}{*}{.46} \\
\hline & 2. Mesleki Tek. & 124 & 3.01 & .68 & & & & & \\
\hline & 3. Din Öğretimi & 73 & 4.22 & .39 & & & & & \\
\hline \multirow[t]{3}{*}{ Zorlayıcılık } & 1. Genel Ort. & 173 & 2.45 & 1.1 & \multirow{3}{*}{$\begin{array}{c}2 ; \\
367\end{array}$} & \multirow{3}{*}{5.375} & \multirow{3}{*}{$.005^{*}$} & \multirow{3}{*}{$\begin{array}{c}1-2 ; 1-3 \\
2-3\end{array}$} & \multirow{3}{*}{.41} \\
\hline & 2. Mesleki Tek. & 124 & 3.65 & .77 & & & & & \\
\hline & 3. Din Öğretimi & 73 & 4.76 & .22 & & & & & \\
\hline \multirow[t]{3}{*}{ Sinırlayıcılık } & 1. Genel Ort. & 173 & 2.54 & 1.03 & \multirow{3}{*}{$\begin{array}{c}2 ; \\
367\end{array}$} & \multirow{3}{*}{5.029} & \multirow{3}{*}{$.007^{*}$} & \multirow{3}{*}{$1-3 ; 2-3$} & \multirow{3}{*}{.37} \\
\hline & 2. Mesleki Tek. & 124 & 2.71 & 1.01 & & & & & \\
\hline & 3. Din Öğretimi & 73 & 4.23 & .15 & & & & & \\
\hline \multirow[t]{3}{*}{ Yardımseverlik } & 1. Genel Ort. & 173 & 4.57 & .35 & \multirow{3}{*}{$\begin{array}{c}2 ; \\
367\end{array}$} & \multirow{3}{*}{2.961} & \multirow{3}{*}{.053} & \multirow{3}{*}{-} & \multirow{3}{*}{.12} \\
\hline & 2. Mesleki Tek. & 124 & 4.69 & .23 & & & & & \\
\hline & 3. Din Öğretimi & 73 & 4.18 & .65 & & & & & \\
\hline \multirow[t]{3}{*}{ Otoriterlik } & 1. Genel Ort. & 173 & 3.91 & .59 & \multirow{3}{*}{$\begin{array}{c}2 ; \\
367\end{array}$} & \multirow{3}{*}{2.818} & \multirow{3}{*}{.061} & \multirow{3}{*}{ - } & \multirow{3}{*}{.09} \\
\hline & 2. Mesleki Tek. & 124 & 4.43 & .31 & & & & & \\
\hline & 3. Din Öğretimi & 73 & 4.02 & .48 & & & & & \\
\hline \multirow[t]{3}{*}{ Yararcılık } & 1. Genel Ort. & 173 & 3.28 & .86 & \multirow{3}{*}{$\begin{array}{c}2 ; \\
367\end{array}$} & & & & \\
\hline & 2. Mesleki Tek. & 124 & 3.83 & .55 & & 4.394 & $.013^{*}$ & $2-3$ & .33 \\
\hline & 3. Din Öğretimi & 73 & 4.26 & .36 & & & & & \\
\hline Yönlendiricilik & 1. Genel Ort. & 173 & 3.79 & .53 & & & & & \\
\hline & 2. Mesleki Tek. & 124 & 3.12 & .62 & $\begin{array}{c}2 ; \\
367\end{array}$ & 2.555 & .079 & - & .06 \\
\hline & 3. Din Öğretimi & 73 & 3.35 & .56 & & & & & \\
\hline Praetoryanizm & 1. Genel Ort. & 173 & 3.27 & .76 & 2. & & & $1-2: 1-3$ & \\
\hline Davranışı & 2. Mesleki Tek. & 124 & 3.63 & .59 & 367 & 3.506 & $.031^{*}$ & $2-3$ & .26 \\
\hline & 3. Din Öğretimi & 73 & 4.14 & .41 & & & & & \\
\hline
\end{tabular}

(*) $\mathrm{p}<.05$

Tablo 8 incelendiğinde, praetoryanizm davranışı okul türü değişkenine göre anlamlı olarak farklılaşmaktadır $\left(\mathrm{F}_{(2 ; 367)}=3.506 ; \mathrm{p}<.05\right)$. Din öğretimi temelli okullarda çalışan okul müdürleri $(\overline{\mathrm{X}}=4.14)$, mesleki ve teknik temelli $(\overline{\mathrm{X}}=3.63)$ okullar ile genel ortaöğretim $(\overline{\mathrm{X}}=3.27)$ okullarında çalışanlara göre daha fazla praetoryanist davranışlar sergilemektedirler. Ayrıca mesleki ve teknik temelli okullarda çalışan katılımcıların da genel ortaöğretim okullarında çalışanlara göre daha fazla praetoryanist davranışlar gösterdikleri saptanmıştır. Okul türü değişkeni praetoryanizm davranışını orta düzede etkilemektedir $\left(d_{\text {Cohen }}<.80\right)$.

\section{Tartışma, Sonuç ve Öneriler}

$\mathrm{Bu}$ çalışma, okul müdürlerinin praetoryanist davranış biçimlerini gösterme düzeylerini belirlemeyi amaçlamıştır. Araştırma sonucunda, okul müdürlerinin en çok sahip oldukları praetoryanist davranışın, 'yardımseverlik' olduğu belirlenmiştir. Ayrıca sırasıyla otoriterlik, yararcılık, zorlayıcılık ve yönlendiricilik davranışlarını da göstermektedirler. Bununla birlikte okul müdürleri, praetoryanizmin 'olumsuz eleştiri' ile 'sınırlayıcılık' boyutlarındaki davranışlara kısmen sahiptirler. Yine araştırma sonucunda okul müdürlerinin çoğunlukla praetoryanist davranışlar içinde olduğu belirlenmiştir. Araştırmanın bu bulguları Ling'in (2003) araştırma bulgularını desteklemektedir. Ancak Cunliffe (2014) özellikle batı kültürel değerlerinin bir sonucu olarak praetoryanist davranışların görülebileceğini ve bu praetoryanist davranışın, özgün bir sosyal etkileşimle öğrenilen bir davranış olduğunu bildirmektedir. Cunliffe'e göre (2014), otoriterlik, olumsuz eleş̧tiri, zorlayıcılık, yararcılık ile sınırlayıcılık gibi davranışlar, praetoryanizmin karanlık yönüdür. Ma ve Tsui (2015) praetoryanizmin 
yardımseverlik ve yönlendiricilik boyutlarının doğu kültürel formlarına vurgu yaptı̆̆ını ve kavramın aydınlık yönünü ön plana çıkardığını savunmaktadırlar.

Araştırmanın yukarıda anılan sonuçlarından hareketle, doğu ve batı kültürel değerleri arasındaki farklılaşmada göz önünde bulundurularak, praetoryanist eğilimler gösteren bir toplumsal yapı içerisinde faaliyetlerini sürdüren bir örgütün de praetoryanist özellikler göstermesinin olası olduğu düşüncesi (Archer, 1990; Beehner, 2018) doğrulanmıştır. Bununla birlikte Türk kültüründeki kolektivist yapı ve geniş güç mesafesinden önemli ölçüde etkilenen örgütler, praetoryanist davranışların çalışma yaşamındaki varlığını görünür kılmaktadır (Dikili, 2014). Örgüt içerisindeki yönetim modellerinin, örgüt külttürünün etkisinde kalması sonucunda, praetoryanist yönetim eğilimleri ortaya çıkabilmektedir (Güçlü, 2003). Bunun neticesinde, yöneticiler çalışanlarına karşı yakın ilgi göstermekte ve çalışanlar da bunun karşılığında liderlerine karşı sayg1 ve itaat göstermektedir. Bu karşılıklı ilişki yöneticinin, kendi otoritesini çalışanına zorla kabul ettirmesine evirilmekte (Vural, 2018); sonuçta, praetoryanist liderlik adında kültürel bir liderlik yaklaşımı ortaya çıkmaktadır (Decalo, 1975; Danopoulos ve Zirker, 2002). Araştırma sonuçlarını dikkate alarak bu kültürel liderlik yaklaşımının, örgüt yönetim ve fonksiyonlarına hem negatif hem pozitif etkisi olduğunu belirtmek yanlış olmayacaktır. Praetoryanist yönetim modeli, temelde yönetici ile çalışanın yakın iliş̧ki kurmasını esas aldığından, çalışan üzerinde olumlu bir etkisi olmadığı düşünülebilmektedir (Giroux, 2018). Böylece, çalışanlar yüksek iş tatmini, duygusal bağlılık gibi birtakım pozitif tutumlar geliştirememektedirler. Bu negatif tutumların çalışanların örgütsel davranışlarına da yansıyacağı (Cunliffe, 2014) varsayımından hareketle, çalı̧̧anların performansında önemli bir artış beklenilmemektedir. Çalışanların performansının artmadığı bir ortamda örgütün verimliliğinin de artmayacağı aşikârdır. Dolayısıyla hem örgüt hem de çalışanlar amaçlarına ulaşmamış olacaklardır. Bunun yanında yöneticinin baskıcı, eleştirel ve zorlayıcı tutum ve davranışları, çalışanlar üzerindeki iş stresinin artmasına ve onların özgürlüklerinin sinırlandırılmasina da neden olacaktır (Adams ve Balfour, 2014; Harpe, 2015; Vural, 2018).

Araştırmanın diğer bir sonucu da praetoryanist davranışlar ile cinsiyetin farklılaşması durumudur. Araştırmaya göre praetoryanizm davranışını kadınların, erkeklere göre daha fazla sergiledikleri bulunmuştur. Alanyazında bu çalışma bulgusunu destekleyen farklı çalışmalar bulunmaktadır. Raviot (2017) ve Jarausch (2014) kadınların, erkeklere göre daha fazla praetoryanist davranış gösterme eğiliminde olduklarını bildirmektedirler. Praetoryanist davranışın cinsiyetle ilişkisinin incelendiği çeşitli araştırma sonuçları, bu araştırmanın sonuçlarıyla farklılık göstermektedir. Rizvi (2015) ve Cunliffe (2014), erkeklerin praetoryan davranışlarının kadınlara göre daha fazla olduğunu bulgulamışlardır. Kadın okul müdürlerinin, praetoryanizmin zorlayıcılık, sınırlayıcılık, otoriterlik, olumsuz eleştiri gibi negatif davranışlara erkeklere göre daha fazla sahip olması, yalnızca praetoryanist eğilimlere ilişkin bir sonuç değildir. Böylesi bir sonuç, kadın ve erkek yönetim biçimleri arasındaki farklılaşmayı da görünür kılmaktadır. Bunun yanında erkeklerin yardımsever davranışları kadınlara göre daha fazla tercih etmeleri de bir ikilem olarak belirmektedir. Ma ve Tsui (2015), praetoryanist yöneticinin aynı zamanda yardımsever veya otoriter olabileceğini ve bu durumun doğu kültürel değerleri için alışıldık olduğunu bildirmişlerdir. Cunliffe (2014) ve Kowalevski (1991) ise batı kültürlerinde bu ikilemin bir yönetim kusuru veya illiberal tutum olarak görülebileceğini bildirmektedirler.

Bağımsız değişkenlerden mesleki kıdem ile praetoryanizm davranışları arasındaki farklılaşma olmadığı sonucu alanyazındaki çeşitli çalışmalarla benzerlik göstermektedir (Raviot, 2017; Cunliffe, 2014; Bowman, 2010). Raviot (2017), mesleki kıdemi az veya yöneticilik tecrübesi az olan yöneticilerin, örgüt içi disiplini yeterince sağlayamadığını; Cunliffe (2014) ise mesleki kıdemi fazla olan yöneticilerin, çalışanlarını daha fazla kontrol ettiklerini bildirmektedir. Bowman (2010), mesleki kıdemdeki artışın yöneticinin praetoryanist davranışlar gösterme eğilimini arttırmadığını ancak daha genç yaşlarda olan yöneticilerin daha fazla praetoryanist davranış kalıpları sergilediğini bildirmektedir. Bowman'a göre (2010) bu durumun sebebi genç yaşlardaki yöneticilerin, kendilerinden daha yaşlı çalışanlar üzerinde otorite kurmakta zorlanmaları veya daha yaşlı çalışanları gerektiği kadar motive edememeleridir. Bunun yanında okul müdürlerinin eğitim durumları ile praetoryanist davranışları arasındaki farklılık da alanyazında çeşitli araştırma sonuçlarıyla paralellik göstermektedir (Ma ve Tsui, 2015; Rizvi, 2015; Peruzzotti, 2004). Rizvi (2015), daha üst eğitim seviyesindeki yöneticilerin, daha az praetoryanist davranışlara sahip olduğunu; Peruzzotti (2004), düşük eğitim seviyesindeki yöneticilerin daha baskıcı ve sert yönetim sergilediklerini bildirmişlerdir. Bu noktada araştırmanın, lisans mezunu okul müdürlerinin, lisansüstü mezunlarına göre daha fazla praetoryanist davranışlar sergiledikleri bulgusu, Ma ve Tsui'nin (2015) 'eğitim seviyesindeki artışın kültürel geçişler yaratabileceği ve özellikle doğu kültüründen batı kültürel değerlerine geçişlerin olabileceği' düşüncesini destekler niteliktedir. Ancak lisansüstü öğrenimler, okul yöneticisi olarak görevlendirilmede dikkate alınmadığından pek çok okul yöneticisi adayı tarafından bu eğitime ilgi 
gösterilmemektedir. Lisansüstü seviyelerde eğitim almanın ve alanda uzmanlaşmanın önemi bilinse de eğitim politikası belirleyici tarafından bu eğitimler önemsenmemektedir. Eğitim politikası belirleyicilerinin, okul yöneticisi yetiştirme politikalarını sürekli değiştirmeleri, yaygın ve sürdürülebilir bir düzlemde okul yöneticisi seçme siyasalarını geçersiz kılmaktadır. Bu araştırma sonucuyla belirlenen kamu okullarında çalışan yöneticilerin, özel okullarda çalışan meslektaşlarına göre daha fazla praetoryanist davranışlar sergiledikleri bulgusu önemlidir. $\mathrm{Bu}$ araştırma ile ayrıca okul müdürlerinin çalıştığı okul türü ile praetoryanist davranışlar arasındaki ilişkiler de incelenmiştir. Buna göre din öğretimi yapan okullarda çalışan müdürlerin, diğer okullarda görev yapan meslektaşlarına göre daha fazla praetoryanist davranışlar sergilediği bulunmuştur. Araştırmanın bu sonucu, Jarausch (2014) tarafından yapılan Katolik okullarında ve diğer din öğretimi yapan okullarda çalışan yöneticilerin daha fazla praetoryanist davranışlar sergilediklerine yönelik araştırma sonuçlarıyla benzerlikler göstermektedir.

$\mathrm{Bu}$ çalışma sonucunda praetoryanizm davranışlarııın erkeklerden ziyade, kadın okul yöneticilerinde daha yüksek düzeyde olduğunun belirlenmesi, kadın yöneticilerin çalışanlarını daha fazla gözettikleri, bunun yanında çalışanların iş ve sosyal yaşantılarına da daha fazla müdahil olduklarını belirginleştirmiştir. Çalışanlar ile sosyal iletişimler kurmak ve çalışma ortamlarını çalışanlar lehine düzenlemek proaktif bir yönetim modeli olsa da praetoryanist davranışlar, çalışanların yaşam ve çalışma biçimlerine müdahale ve sınırlandırmaları da içermektedir. Yetişkinlerde davranış değişikliği yapılabilmesi oldukça zor ve uzun süreli çalışma gerektiren bir süreçtir ve davranışlar dışsal baskılardan ziyade kişinin içsel ve öznel farkındalığı ve değişim isteği ile gerçekleştirilebilir. Bu araştırmanın önemli sonuçların biri de okul türü değiş̧eni ile praetoryanizm arasındaki ilişkinin ortaya çıkarılmasıdır. Din öğretimi temelli okullarda çalışan katılımcıların, mesleki ve teknik temelli okullar ile genel ortaöğretim okullarında çalışan katılımcılara göre daha fazla praetoryanist davranışlar sergilemeleri önemlidir. Okullarda müdürlerin praetoryanist davranışlar sergilemesi, gerçekte, okulun başarısı veya verimini arttırma amacı taşır. Ayrıca, çalışanlarına karşı yardımsever ve yönlendirici davranışlar sergileyen müdürlerin, çalışma ortamlarını daha çalışılabilir kılması da söz konusudur. Çalışanların ihtiyaçlarını karşılayan ve çalışanlarına yakın ve sıcak bir özen gösteren yöneticinin, çalışanlarından benzer bir tutum ve davranış beklemesi yaşamın doğal akışıdır. Ancak praetoryanizm, yarar ve çıkar ilişkilerinin normatif kalıplardan çok sosyolojik bir biçimde takasını öngörür. Yani praetoryanizmdeki karşılıklılık ilkesi, yarar ve çıkar ilişkilerine dayalı bir iktidarın meşrulaşmasını öngörmektedir. Sunulan tartışmalara ek olarak bu çalışma, okul müdürlerinden oluşan evren çerçevesinde yürütülmüş ve burada sunulan veriler, doğrudan katılımcı görüşlerinden elde edilmiştir. Farklı evrenlerle elde edilen veriler kullanılarak yürütülen araştırmalarda farklı bulgulara ulaşılabilir. Üçüncü taraf gözlemcilerin kullanıldığı araştırmalarda praetoryanizmin, vesayet ve statükoya yol açma özelliği nedeniyle yönetici veya eş düzey meslektaşların önyargılı davranabilecekleri hususu göz önünde bulundurulmalıdır. Ayrıca alanyazındaki praetoryanist davranış biçimleriyle ilgili çalışmaların önemli bir kısmı eğitim dışı örgütlerde gerçekleştirilmiştir. Alanyazında eğitim örgütü yöneticilerinin sergiledikleri praetoryanist davranış biçimlerine ilişkin henüz yeterli nicel ve nitel çalışmanın bulunmadığı ifade edilebilir. Bu nedenle okul müdürlerinin hangi tür praetoryanist davranışı hangi sıklıkla sergiledikleri konusu gelecekteki çalışmalar için önemli bir kuramsal tartışma alanına dönüşebilir. Aynı şekilde demografik ve örgütsel faktörlerin okul müdürlerinin praetoryanist davranış biçimleri üzerinde etkili olup olmadığı, praetoryanist davranışların nedenleri ve sonuçları gibi konularla ilgili alanyazında yeterli sayıda çalışma bulunmamaktadır. Bu çalışmada cinsiyet, mesleki kıdem, eğitim durumu, okul türü ve kamu-özel okul ayrımı gibi bireysel ve örgütsel düzeydeki değişkenler çalışmaya dâhil edilmiştir. Araştırma, Ankara İline bağlı ilçelerdeki kamu ve özel liselerde görevli okul müdürlerinin praetoryanizm ölçeğine iliş̧in görüşleri ile sınırlıdır. Toplumsal, sosyal ve ekonomik değişiklikler ile eğitim sisteminde oluşabilecek beklenmedik durumlar, praetoryanizm davranışa ilişkin görüşlerin değişmesine neden olabilir ve araştırmanın güncelliğini geçersiz kılabilir. Bu sebeple araştırmanın farklı yıllarda boylamsal çalışmalarla sınanması önemli görülebilir.

Araştırma sonuçlarından hareketle geliştirilen öneriler aşağıdaki gibi sıralanabilir:

- Okullarda sağlıklı çalışma ortamlarının oluşturulması için olumsuz praetoryanist davranışlar sergileyen yöneticilerin, kendi davranışlarını fark etmeleri sağlanmalıdır. Bu amaçla belirli zamanlarda okul yöneticileri için 'çalışanlar tarafından değerlendirilme', 'kendini değerlendirme' veya 'performans değerlendirme' formları düzenlenerek dış denetim mekanizmalarının işlerliği sağlanmalıdır.

- Yöneticilerin dışsal bir baskı veya eleştiri olmaksızın kendi davranışlarının farkında olmaları ve davranışlarının sonuçlarına ilişkin empati yapmaları sağlanmalıdır. $\mathrm{Bu}$ amaçla, praetoryanizmin, yardımseverlik ve 
yönlendiricilik gibi olumlu yöndeki davranışları destekleyen ve zorlayıcılık gibi olumsuz etkileri olabilecek davranışları söndürmeye yönelik kişisel gelişim planları hazırlanmalıdır.

- Praetoryanist davranış sergileyen yöneticilerin, ideal yönetici davranışlarına yönlendirilmesi amacıyla mentorluk ve koçluk yaklaşımlarından yararlanmaları sağlanmalıdır.

- Bu araştırma sonuçları dikkate alınarak okul yöneticilerinin lisansüstü eğitimlere yönlendirilmesi önerilebilir. Lisansüstü seviyede eğitim almaları için okul yöneticilerinin teşvik edilmesi, eğitim politikasına yön verenlere bir öneri olarak sunulabilir.

- Din öğretimi temelli okullarda çalı̧an müdürlerin olumsuz praetoryanist davranışlar sergilemeleri bu okullarda düzenlenecek hizmet içi eğitimler veya okul müdürlerine yönelik psikososyal gelişim planları ile azaltılabilir. Sürdürülebilir bir gelişimin planı ile kayda değer gelişim sağlanabilir. Bu amaçla hangi okul türünde görev yaptığına bakılmaksızın tüm okul yöneticilerini kapsayacak uygulamalı bir iletişim eğitimi ile yine uygulamalı eğitim yönetimi eğitimleri hazırlanabilir.

- Bu çalışmanın farklı değişkenleri (kişilik özellikleri, örgütsel davranışın farklı kavramları vb.) de dikkate alacak şekilde genişletilmesi ileride yapılacak araştırmalar için önerilebilir. Ayrıca ileride yapılacak araştırmalarda, nitel araştırma yöntemlerinin işe koşulması ile kavrama ilişkin daha derin incelemelerin yapılması önerilebilir. 


\section{References}

Adams, G., \& Balfour, D. (2014). Unmasking administrative evil. New York: Routledge.

Adeniran, T. (1985). Military rule and nation-building: praetorianism revisited. The Nigerian Journal of Economic and Social Studies, 27(3), 329-344.

Alexander, L. (2001). Illiberalism all the way down: Illiberal groups and two conceptions of liberalism. $J$. Contemp. Legal Issues, 12, 625.

Altemeyer, B. (1988). Enemies of freedom: Understanding right-wing authoritarianism. New York: Jossey-Bass.

Archer, C. I. (1990). The Royalist Army of New Spain, 1810-1821: Militarism, Praetorianism, or Protection of Interests?. Armed Forces \& Society, 17(1), 99-116.

Baltac1, A. (2018). Örgütsel praetoryanizm: kavramsal temellerin arkeolojisi [Organizational Praetorianism: Archaeology of Conceptual Foundations]. Kirlkkale Üniversitesi Sosyal Bilimler Dergisi, 8(2), 497-522.

Baron, R. A. (1988). Negative effects of destructive criticism: Impact on conflict, self-efficacy, and task performance. Journal of Applied Psychology, 73(2), 199.

Beehner, L. M. (2018). A Means of First Resort: Explaining "Hot Pursuit" in International Relations. Security Studies, 1-31.

Ben-Eliezer, U. (1997). Rethinking the Civil-Military Relations Paradigm: the inverse relation between militarism and praetorianism through the example of Israel. Comparative Political Studies, 30(3), 356-374.

Bowman, K. S. (2010). Militarization, democracy, and development: The perils of praetorianism in Latin America. Pennsylvania: Penn State Press.

Bowman, K. (2002). Militarization, Development, and Democracy: The Perils of Praetorianism in Latin America. Pennsylvania: Penn State Press.

Cann, R., \& Danopoulos, C. (1998). The military and politics in a theocratic state: Iran as case study. Armed Forces \& Society, 24(2), 269-288.

Cunliffe, P. (2014). The New Liberal Praetorianism. H-Diplo, 280.

Danopoulos, C. P. (1984). Warriors and politicians in modern Greece (Vol. 1). London: Documentary Publications.

Danopoulos, C., \& Zirker, D. (2002). Civil-military relations theory in the post-communist world. Geneva Centre for the Democratic Control of Armed Forces, 38, 1-23.

Decalo, S. (1975). Praetorianism, Corporate Grievances and Idiosyncratic Factors in Military Hierarchies. Journal of African Studies, 2(2), 247.

Dikili, A. (2014). Örgütlerde Güç Kavramı: Eleştirel Yönetim Çalışmaları İle Kaynak Bağımlılığı Yaklaşımı’nın Bakışlarına Dair Karşılaştırmalı Bir Analiz [Concept of Power in Organisations: A Comparative Analysis of Critical Management Studies and Resource Dependence Perspective]. Yönetim Bilimleri Dergisi, 12(23), 141164.

Egreteau, R. (2016). Embedding praetorianism: soldiers, state, and constitutions in postcolonial Myanmar. In Politics and constitutions in Southeast Asia (pp. 131-153). New York: Routledge.

Eyal, O., \& Kark, R. (2004). How do transformational leaders transform organizations? A study of the relationship between leadership and entrepreneurship. Leadership and Policy in Schools, 3(3), 211-235.

Gaub, F. (2017). Like father like son: Libyan civil-military relations before and after 2011. Mediterranean Politics, 1-15.

Giroux, H. A. (2018). Terror of Neoliberalism: Authoritarianism and the Eclipse of Democracy. New York: Routledge.

Güçlü, N. (2003). Örgüt kültürü [Organizational Culture]. Gazi Üniversitesi Sosyal Bilimler Dergisi, 23(2), 61-85. 
Hansen, R., \& King, D. (2000). Illiberalism and the new politics of asylum: liberalism's dark side. The Political Quarterly, 71(4), 396-403.

Harpe, S. E. (2015). How to analyze Likert and other rating scale data. Currents in Pharmacy Teaching and Learning, 7(6), 836-850.

Hen-Tov, E., \& Gonzalez, N. (2011). The militarization of post-Khomeini Iran: praetorianism 2.0. The Washington Quarterly, 34(1), 45-59.

Herspring, D. R. (1992). Civil-military relations in post-communist Eastern Europe: The potential for praetorianism. Studies in Comparative Communism, 25(2), 99-122.

Jarausch, K. H. (2014). Students, Society and politics in imperial Germany: The rise of academic illiberalism. New Jersey: Princeton University Press.

Kerfoot, D., \& Knights, D. (1993). Management, masculinity and manipulation: From praetoryanism to corporate strategy in financial services in Britain. Journal of Management Studies, 30(4), 659-677.

Kowalewski, D. (1991). Periphery praetorianism in cliometric perspective 1855-1985. International Journal of Comparative Sociology, 32(3), 289-303.

Lakens, D. (2013). Calculating and reporting effect sizes to facilitate cumulative science: a practical primer for ttests and ANOVAs. Frontiers in Psychology, 4, 863.

Ling, Y. (2003). From praetorianism to democracy [J]. Journal of Shijiazhuang Teachers College, 2, 015.

Ma, L., \& Tsui, A. S. (2015). Traditional Chinese philosophies and contemporary leadership. The Leadership Quarterly, 26(1), 13-24.

Maier, S. F., \& Seligman, M. E. (1976). Learned helplessness: Theory and evidence. Journal of Experimental Psychology: General, 105(1), 3.

McLauchlin, T. (2010). Loyalty strategies and military defection in rebellion. Comparative Politics, 42(3), 333350.

Mulford, B. (2003). School leaders: Changing roles and impact on teacher and school effectiveness. New York: Education and Training Policy Division, Oecd.

Nordlinger, E. A. (1977). Soldiers in politics: military coups and governments. London: Prentice Hall.

Peruzzotti, E. (2004). From praetorianism to democratic institutionalization: Argentina's difficult transition to civilian rule. Journal of Global South Studies, 21(1), 97.

Raviot, J. R. (2017). Russian Praetorianism: exercising power according to Vladimir Poutine. Hérodote, (3), 9-22.

Rizvi, A. J. (2015). Civil-Military-Islamist Relations: An Opinion on Democracy, Islamist Militancy and Praetorianism in Pakistan. New York: Prentice Hall.

Seligman, M. E. (2005). Helplessness: On depression, development and death. London: WH Freeman \& Co..

Vogt, W. P. (2006). Quantitative research methods for professionals in education and other fields. Columbus: Allyn \& Bacon.

Vural, Z. B. A. (2018). Kurum kültürü [Organizational Culture]. Ankara: İletişim Yayınları. 